\title{
Sucesión de normas administrativas sancionadoras: irretroactividad y excepciones
}

\section{Succession of sanctioning administrative rules: non-retroactivity and exceptions}

\author{
Manuel Rebollo Puig \\ Universidad de Córdoba (España) \\ ORCID: https://orcid.org/0000-0002-4803-7967 \\ manuel.rebollo.puig@uco.es
}

\section{NOTA BIOGRÁFICA}

Catedrático de Derecho Administrativo en la Universidad de Córdoba desde 1994. Líneas de investigación: Fuentes del Derecho, organización, actividad, medios y control de la Administración pública, Derecho Administrativo sancionador.

\section{RESUMEN}

En Derecho Administrativo sancionador se parte de reglas claras sobre la retroactividad o irretroactividad de sus normas. Pero su aplicación suscita dudas. Para solventarlas, se ha analizado separadamente la regla de la prohibición de la retroactividad desfavorable y la de la obligada retroactividad favorable. Las soluciones que se ofrecen respecto a la primera, cuyos fundamentos son sólidos, tienden a su radical entendimiento; pero se excluye de su ámbito las normas procedimentales y las relativas a la ejecución de las sanciones. Además, se aborda la cuestión del momento en que han de entenderse cometidas las infracciones. Muy distinto es el enfoque que merece la regla de la obligada retroactividad favorable, de fundamento positivo y material más endeble. Con ese punto de vista, se trata de restringir su ámbito de aplicación para no llevarla más allá de los casos en que el legislador ha cambiado su valoración negativa de la conducta. Asimismo, se analiza hasta qué momento cabe esta aplicación retroactiva. Y para ambas reglas se exponen las consecuencias de su violación y las vías de reacción.

\section{PALABRAS CLAVE}

Infracciones y sanciones administrativas; Retroactividad e irretroactividad.

\begin{abstract}
This paper analyses the principle of non-retroactivity and its application in the field of administrative sanctions, where there are clear rules about the retroactivity and the non-retroactivity of sanctioning norms but also doubts about its application. To solve them, the principle of non-retroactivity of unfavourable rules is studied as well as the rule of obligatory favourable retroactivity. Regarding the first principle, its validity seems peaceful, although its application is excluded with respect to procedural norms and those related to the execution of sanctions. Also, it is analysed the moment when the infractions must be understood to have been committed. The rule of favourable retroactivity is studied in a very different way. It is intended to restrict its scope of application to implement this rule only in cases in which the legislator has changed his negative assessment of the conduct. It also analyses up to what point this rule can be applied. Finally, this work exposes the consequences of the violation of both rules, as well as the possible ways of reaction.
\end{abstract}

\section{KEYWORDS}

Administrative offences and sanctions; Retroactivity and non-retroactivity. 
REALA. Nueva Época - N. 16, octubre 2021 - ISSN: 1989-8975 - DOI: https://doi.org/10.24965/reala.i16.10961 - [Págs. 6-32]

Sucesión de normas administrativas sancionadoras: irretroactividad y excepciones

Manuel Rebollo Puig

\begin{abstract}
SUMARIO
1. LAS DOS REGLAS QUE DISCIPLINAN LA SUCESIÓN DE NORMAS PUNITIVAS. DISTINCIÓN ENTRE NORMA POSTERIORES FAVORABLES Y DESFAVORABLES. 2. LA PROHIBIDA RETROACTIVIDAD DE LAS NORMAS SANCIONADORAS DESFAVORABLES. 2.1. FUNDAMENTO. 2.2. ELEMENTOS DE LAS NORMAS SANCIONADORAS CON RETROACTIVIDAD IN PEIUS PROHIBIDA. 2.3. IRRETROACTIVIDAD IN PEIUS DE REGLAMENTOS EJECUTIVOS Y DE CRITERIOS INTERPRETATIVOS. 2.4. IRRETROACTIVIDAD IN PEIUS DE LAS NORMAS NO SANCIONADORAS EN CUANTO SE INTEGRAN CON LAS SANCIONADORAS. 2.5. IRRETROACTIVIDAD DE LA HABILITACIÓN LEGAL A REGLAMENTOS SANCIONADORES. 2.6. EXCLUSIÓN DE LAS NORMAS PROCEDIMENTALES. 2.7. SOBRE LAS NORMAS RELATIVAS A LA EJECUCIÓN DE LAS SANCIONES. 2.8. MOMENTO EN QUE HAN DE ENTENDERSE COMETIDAS LAS INFRACCIONES A ESTOS EFECTOS. 2.9. CONSECUENCIAS DE LA VULNERACIÓN DE LA REGLA Y CAUCES PARA ELIMINARLA. 3.. LA OBLIGADA RETROACTIVIDAD DE LAS NORMAS SANCIONADORAS FAVORABLES. 3.1. FUNDAMENTO. 3.2. ELEMENTOS DE LAS NORMAS SANCIONADORAS CON OBLIGADA RETROACTIVIDAD IN BONUS. 3.3. LA EXCEPCIÓN DE LAS NORMAS TEMPORALES Y DE ACTUALIZACIÓN DE IMPORTES ECONÓMICOS. 3.4. RETROACTIVIDAD IN BONUS DE REGLAMENTOS EJECUTIVOS Y DE CRITERIOS INTERPRETATIVOS. 3.5. ¿RETROACTIVIDAD IN BONUS DE LAS NORMAS NO SANCIONADORAS EN CUANTO SE INTEGRAN CON LAS SANCIONADORAS? LA RESPUESTA DOMINANTE Y LA CONVENIENTE MATIZACIÓN. 3.6. RETROACTIVIDAD DE LAS LEYES QUE DAN COBERTURA A REGLAMENTOS FAVORABLES. 3.7. SOBRE LAS NORMAS PROCEDIMENTALES Y LAS RELATIVAS A LA EJECUCIÓN DE LAS SANCIONES. 3.8. INTRASCENDENCIA DEL MOMENTO EN QUE SE COMETIERA LA INFRACCIÓN. 3.9. PROCEDE ESTA APLICACIÓN RETROACTIVA MIENTRAS NO SE HAYA EJECUTADO LA SANCIÓN Y MIENTRAS, INCLUSO EJECUTADA, NO SEA FIRME. 3.10. CONSECUENCIAS DE LA VIOLACIÓN DE LA REGLA Y CAUCES PARA ELIMINARLA.
\end{abstract}

\title{
1. LAS DOS REGLAS QUE DISCIPLINAN LA SUCESIÓN DE NORMAS PUNITIVAS. DISTINCIÓN ENTRE NORMA POSTERIORES FAVORABLES Y DESFAVORABLES
}

A diferencia de lo que sucede en otros sectores del ordenamiento, en el Derecho Administrativo sancionador, como en el Penal, hay reglas claras sobre la posibilidad y hasta obligatoriedad de la retroactividad o irretroactividad.

El artículo 26.1 de la Ley 40/2015, de 1 de octubre, de Régimen Jurídico del Sector Público (en adelante LRJSP) proclama como regla general la de la aplicabilidad de la norma sancionadora vigente «en el momento de producirse los hechos que constituyan infracción administrativa»; para ser más, exactos, en el momento de cometerse la acción (u omisión) imputada como infracción administrativa. Por tanto, excluye la retroactividad de las normas sancionadoras. Es lo que da sentido al rubro del artículo: «Irretroactividad».

Pero esa regla general tiene de inmediato una excepción: la relativa a las normas sancionadoras posteriores más favorables que las existentes en el momento del acto enjuiciado. Estas sí pueden y deben aplicarse retroactivamente; esto es, pueden y deben aplicarse a las acciones realizadas antes de su entrada en vigor. Lo establece el artículo 26.2 LRJSP.

En realidad, más que una regla general y una excepción, hay dos reglas que se reparten el campo: la de la irretroactividad de las normas sancionadoras desfavorables (o sea, la prohibición de retroactividad in peius o in malam partem); y la de la obligada retroactividad de las normas sancionadoras favorables (o simplemente retroactividad favorable o benigna o in bonam partem o in bonus o in melius). Y es así como lo formula, por ejemplo, el Estatuto Básico del Empleado Público [ahora artículo 94.2.b) del Texto Refundido de 2015] que simplemente afirma que «la potestad disciplinaria se ejercerá de acuerdo con (el) principio de irretroactividad de las disposiciones sancionadoras no favorables y de retroactividad de las favorables al presunto infractor». Por tanto, si cambian las disposiciones sancionadoras, o está prohibida su retroactividad o es obligada según la nueva regulación sea desfavorable o favorable. Aparentemente no hay supuestos en los que la nueva norma sancionadora pueda decidir con libertad sobre su retroactividad.

Con esta proclamación, como con la que existe en el Derecho Penal (arts. 2 y 7 CP), no sólo se ha dejado claro el respectivo ámbito de la prohibida retroactividad in peius y de la obligada retroactividad in bonus, sino que se expresa inequívocamente qué se entiende a estos efectos por retroactividad y por irretroactividad. Por eso aquí no se han planteado problemas para perfilar un concepto de retroactividad y 
de irretroactividad ni apenas se ha sentido la necesidad de distinguir la retroactividad de los meros efectos inmediatos o la de diversificar retroactividad de grado máximo, medio y mínimo que sí han presidido -y torturado- las exposiciones en otros ámbitos jurídicos para dilucidar lo que realmente está prohibido y permitido ${ }^{1}$. En nuestra sede la retroactividad es el enjuiciamiento de una acción (u omisión) conforme a normas punitivas que entraron en vigor después de que se cometiera la acción. Si acaso, hay problemas, como se verá, cuando esa acción (u omisión) se prolongó en el tiempo y solo en parte se realizó estando ya vigente la nueva norma. Salvo esto, es seguro que en unos casos la retroactividad está prohibida y en los demás es obligada.

Ambas reglas (la de la prohibición y la de la obligación de retroactividad) presentan aspectos comunes. Pero también muchos singulares de cada una. Incluso tienen distinto fundamento ${ }^{2}$. Por eso, conviene analizarlas separadamente aun a riesgo de resultar reiterativo en algunos aspectos.

Pero hay un aspecto común y previo que sirve para decidir cuál de las dos reglas (la de la prohibida o la de la obligada retroactividad) es de aplicación: determinar si la norma posterior es favorable o desfavorable. A este respecto está asentado en la doctrina y en la jurisprudencia que la comparación debe hacerse entre las dos regulaciones en su conjunto. O sea, no cabe descomponer sus diversos elementos, escoger de cada una lo favorable y excluir lo desfavorable pues «con tal manipulación del contenido de las normas puede llegarse a una descomposición en la unidad y ratio de las dos disposiciones en conflicto, surgiendo un híbrido que no es sino un producto normativo nuevo» (López Menudo, 1982, pp. 195-196). Dice, por ejemplo, la STC 75/2002, de 8 de abril, que procede la «aplicación íntegra de la ley más beneficiosa, incluidas aquellas de sus normas parciales que puedan resultar perjudiciales en relación con la ley anterior» ${ }^{3}$. Pero cuando cambian diversos aspectos no siempre es fácil determinar qué regulación, en su conjunto, es favorable y cuál desfavorable 4 . Más cuando se trata de comparar entre sí leyes administrativas sancionadoras cada una de ellas con vagas reglas para calificar las infracciones como leves, graves o muy graves, con amplias horquillas de sanciones para cada una de ellas y sin precisas atenuantes ni agravantes sino solo desvaídos criterios de graduación de la sanción, de modo que la severidad o benignidad dependerá de cómo se apliquen. Ante ello, se afirma que «hay que operar en concreto y no en abstracto» (Gómez Tomillo y Sanz Rubiales, 2017, p. 190), esto es, hay que atender a la concreta solución que procedería ante una conducta determinada. Incluso se ha dicho que hay que «considerar el modo de vida y proyectos del reo pues, en definitiva, ha de tratarse de una solución más favorable para él» ${ }^{5}$. Por eso, aunque no esté prevista en las leyes de procedimiento, «podría ser de utilidad la traslación al ámbito administrativo sancionador de la previsión incluida en el artículo $2.2 \mathrm{CP}$ de que en caso de duda sobre la determinación de la ley más favorable será oído el reo» (Bueno Armijo, 2010, pp. 207-2089). Puede ser de utilidad y, aun sin previsión legal expresa, es perfectamente posible y recomendable, aunque la opinión del imputado no sea vinculante ${ }^{6}$.

\footnotetext{
Sobre esto es capital la exposición de López Menudo (1982, pp. 42 a 70).
}

2 González Tapia (2002, pp. 216-217) explica que es imposible reducir a un fundamento común la irretroactividad de la norma punitiva desfavorable y la retroactividad de la favorable: obedecen a «exigencias y razones completamente distintas o, mejor dicho, antagónicas». López Menudo (1982, p. 180) dice que «la retroactividad in bonam partem es una institución distinta; no meramente la otra cara del principio de la ley penal más rigurosa; su fundamento y su ratio son diferentes».

3 Igualmente, STC 131/1986, de 29 de octubre y SSTS de 18 de marzo de 2003 (rec. 5721/1998), 15 de octubre de 2008 (rec 717/2006), 9 de marzo de 2010 (rec. 553/2007 y 30 de octubre de 2009 (rec. 334/2006). En esta última se lee: «la aplicación retroactiva de la norma más beneficiosa ha de hacerse determinando qué disposición es más favorable mediante el contraste entre ambas, anterior y posterior, consideradas de modo global, no tomando lo que resulte más beneficioso de una y otra para crear, en realidad, una nueva disposición». También SSTS 1460 y 1467/2020, de 5 de noviembre; 1469, 1471, 1476 y 1477/2020, de 10 de noviembre; 1511 y 1513/2020, de 12 de noviembre; 1562/2020, de 19 de noviembre; y 1620/2020, de 26 de noviembre. Todas estas, ante unos hechos realizados bajo la vigencia de la Ley Orgánica de Protección de Datos de 1999 y la posterior vigencia del Reglamento (UE) 2016/679 y de la Ley Orgánica 3/2018, afirman que la consideración de si son o no más favorables «deriva de su aplicación in toto al caso concreto de que se trate pues solo así se le puede considerar de manera efectiva una norma más favorable para dicho supuesto». Como, valoradas en su conjunto las nuevas normas no resultaban más favorables, negaron su aplicación.

4 Más bien, como afirma Bueno Armijo (2010, p. 207), «parece difícil aportar soluciones de validez general», siendo «materia proclive al desarrollo de una amplia casuística». Igualmente, López Menudo (1982, p. 729).

5 Rodríguez Mourullo (1997, p. 140). Por ejemplo, entre una sanción de multa y otra de pérdida temporal del permiso de conducir, para unos será preferible la primera y para otros la segunda.

6 Lo demuestra la STS de 29 de mayo de 1998 (recurso 3846/1992): según una de las normas la conducta era delito y según otra infracción administrativa; pero el infractor prefería ser castigado por el delito porque comportaba una pena (prisión menor, a la que se podría aplicar la remisión condicional y, por tanto, no cumplirse efectivamente) mientras que a la infracción correspondía una elevada multa. Pero para el TS, en contra de la voluntad del interesado, la norma que tipificaba como delito y preveía pena privativa de libertad es desfavorable respecto a la que la consideraba infracción castigada con multa. 


\section{LA PROHIBIDA RETROACTIVIDAD DE LAS NORMAS SANCIONADORAS DESFAVORABLES}

\subsection{Fundamento}

El fundamento positivo supralegal de la irretroactividad de las normas punitivas desfavorables no ofrece duda. Está claramente consagrada en los artículos 9.3 y $25.1 \mathrm{CE}$, como desde su sentencia 8/1981 ha entendido el TC. Además, es lo que principal e inequívocamente está proclamado en los preceptos de los textos internacionales sobre derechos humanos. Así, en los artículos 11.1 de la Declaración Universal de Derechos Humanos (1948) y 15.1 del Pacto Internacional de Derechos Civiles y Políticos (1966). También en el artículo 7.1 del Convenio Europeo de Derechos Humanos y, a sus efectos, en el artículo 49.1 de la Carta de Derechos Fundamentales de la Unión Europea. No es necesario insistir aquí en que, aunque algunos de esos textos hablan de «delitos» y "penas», según una tendencia generalizada, son aplicables por igual ante infracciones y sanciones administrativas. Por eso, en cuanto a esta prohibición de retroactividad in malam partem no vale la pena analizar el ámbito de aplicación de la LRJSP y su exclusión de las sanciones tributarias, de orden social, de extranjería o de tráfico (disposición adicional primera) u otras (las impuestas por colegios profesionales, por el Consejo General del Poder Judicial, etc.) porque, al margen del artículo 26.1 de esa Ley, tal prohibición ha de regir para todas las manifestaciones del ius puniendi estatal.

Con tal fundamento positivo supralegal, la prohibición de retroactividad in malam partem opera sin dificultades como mandato para la ley ( $y$, claro está, para el reglamento en la modesta medida en que puede ser fuente del Derecho Administrativo sancionador) y como mandato para el aplicador de las normas sancionadoras, o sea, la Administración y, en su caso, el juez contencioso-administrativo.

En cuanto a su fundamento material, está en la seguridad jurídica, pues evita que los ciudadanos se vean sorprendidos por leyes posteriores a sus acciones; sólo con la irretroactividad podrán saber las consecuencias de sus actos y prever la reacción estatal ${ }^{7}$. Así, es complemento necesario de otro de los componentes del principio de legalidad del Derecho punitivo, en concreto, de la tipicidad: de nada servirían las tipificaciones más exquisitas si las normas punitivas pudieran tener eficacia retroactiva desfavorable. Por eso aparece formulada conjuntamente con el principio de legalidad, no solo en los textos internacionales y en las Constituciones, sino también en sus formulaciones doctrinales clásicas: nullum crimen, nulla poena sine praevia lege. Además, el castigo en virtud de leyes posteriores al hecho reprimido no tendría la justificación que se atribuye a las penas y que también hay que reconocer a las sanciones administrativas: ni la de la retribución ni la prevención ${ }^{8}$.

\subsection{Elementos de las normas sancionadoras con retroactividad in peius prohibida}

El artículo 26.1 LRJSP habla de «disposiciones sancionadoras» sin más precisiones. Solo en el apartado siguiente, cuando se consagra la retroactividad in melius, hay especificaciones de interés al referirse concretamente a la tipificación de la infracción, a la sanción y a la prescripción. Esas precisiones valen para lo que ahora nos interesa. Por tanto, no será de aplicación la norma posterior que:

a) Tipifique como infracción una acción que antes era impune o aumente un tipo ya existente (sancione la comisión culposa cuando antes sólo era punible la dolosa; añada nuevos sujetos responsables; etc.). Da igual que la acción ya fuese antijurídica e incluso que tuviera prevista alguna consecuencia negativa no punitiva: lo importante es que la nueva norma establezca un castigo para una conducta que antes no tenía atribuido ninguno.

7 Es radical Ruiz Antón (1991, p. 152): «el fundamento de la prohibición de retroactividad de los delitos y las penas se encuentra -por encima de cualquier otra consideración- en la idea de seguridad jurídica. Razonamientos de diferente índole no son más que un desarrollo consecuente...».

8 Rodríguez Mourullo (1997, p. 131): «Desde el punto de vista político-criminal la irretroactividad se justifica porque una sanción establecida con posterioridad al hecho no podría operar ni como retribución (que supone la violación culpable de la ley, y ésta no existía entonces) ni como prevención (es imposible evitar ya la comisión del hecho efectuada en el pasado)». Y para el Derecho Administrativo Cano Campos (2018, p. 56): «La aplicación retroactiva de las normas sancionadoras hace perder a la sanción toda su función» pues «mal puede incidir en las conductas una norma que se refiera a comportamientos ya realizados o con una amenaza más grave que la existente cuando se realizó». También se ha puesto en conexión con el principio de culpabilidad. Es cierto que la existencia previa de la norma punitiva que el sujeto pudo conocer cuando actuó es presupuesto para afirmar la culpabilidad. Pero, como precisa González Tapia (2002, pp. 157-166), la culpabilidad no puede explicar que no quepa aplicar la ley posterior que simplemente agrava la pena pues para la culpabilidad «resulta del todo irrelevante que el sujeto conozca la clase y gravedad de la pena que corresponda imponer por su comportamiento». 
b) Agrave el castigo previsto anteriormente para un hecho que ya era punible. Puede que tuviese prevista antes una pena o puede que se tratara de una sanción administrativa: lo relevante a estos efectos es que la sanción administrativa establecida en la nueva norma sea más severa que la anterior con independencia de que su imposición correspondiera a los jueces o a la misma Administración. Y ello se puede producir por distintas formas: no sólo con un castigo de igual naturaleza, pero mayor extensión sino con otros de diferente y más aflictiva naturaleza; o por la introducción de una nueva agravante; o por la supresión de una anterior eximente o atenuante; etc. Lo que, sin embargo, no está cubierto por la prohibición que exponemos son las consecuencias de las infracciones que, aunque perjudiciales, no sean propiamente sanciones ${ }^{9}$.

c) Alargue el plazo de prescripción. Se refiere específicamente el artículo 26.2 LRJSP a los plazos de prescripción, pero solo a los efectos de la obligada retroactividad in bonus. Y no distingue entre la prescripción de la infracción y de la sanción. Resulta cuestionable la justificación y acierto de esta previsión legal, como se explicará después. Pero, si se acepta para la retroactividad de las normas favorables, con más razón deben incluirse esas normas sobre prescripción en la prohibida retroactividad in peius ${ }^{10}$. Por tanto, si cuando se cometió una infracción estaba establecido un plazo de prescripción, la norma posterior que prolongue ese plazo no será de aplicación; y es indiferente que esa norma entre en vigor cuando todavía no había pasado el plazo de prescripción inicialmente establecido o cuando ya se había superado. Aunque el artículo 26.2 LRJSP habla precisamente de «plazos de prescripción», igual irretroactividad hay que afirmar respecto a las normas que alteren en contra del infractor el momento de inicio del cómputo o las causas de interrupción.

\subsection{Irretroactividad in peius de reglamentos ejecutivos y de criterios interpretativos}

Todo lo afirmado debe extenderse a los reglamentos que, dentro de las posibilidades que les reconoce el artículo 27.3 LRJSP, desarrollen una ley sancionadora ${ }^{11}$. Por tanto, ante un hecho cometido bajo la vigencia de la ley sancionadora pero antes de la del reglamento de desarrollo, éste no podrá aplicarse si en alguna de las formas vistas perjudica al infractor. Da igual que se considere que lo único que hace es interpretar a la ley previa. Y lo mismo hay que decir en general de las normas meramente interpretativas (aunque sean interpretativas, no ya de la norma sancionadora, sino de las que han de integrarse con ella ${ }^{12}$. Lo que habrá que tener en cuenta será únicamente la norma originaria interpretada conforme a los criterios hermenéuticos generales. Si eventualmente la interpretación a la que por esa vía se llegue coincide con la que le da la norma de desarrollo o interpretativa posterior a los hechos, miel sobre hojuelas: servirá para reforzar la corrección de la interpretación alcanzada, pero no más. Y en ese caso más bien habría que decir que la norma de desarrollo o interpretativa no es realmente desfavorable, sino inocua. Pero si la norma posterior lo que hace es optar entre varias interpretaciones posibles por una que excluye otras más favorables al infractor, la prohibición de retroactividad debe impedir su toma en consideración; más bien su existencia servirá para demostrar que hasta que se aprobó había dudas, con el beneficio para

9 Ofrece ejemplo de ello la STS de 21 de julio de 2009 (recurso 507/2008): aceptó la publicación de una sanción pese a que esto se había previsto en una ley posterior a los hechos sancionados; y fundamentalmente se basó en entender que esa publicación no constituía, ella misma, otra sanción. Sobre esta sentencia y, en general, sobre las consecuencias de considerar una publicación como sanción o no, vid. Huergo Lora (2021, p. 121). Quizá tampoco las normas que prevean estas otras consecuencias puedan ser retroactivas in peius, pero ello ocurrirá eventualmente así en virtud de principios diferentes del que aquí analizamos.

10 Lo que cabe discutir es si esta regla que prohíbe la retroactividad de las normas que alarguen los plazos de prescripción tiene rango supralegal. Me inclino por una respuesta negativa de modo que no sería necesariamente inconstitucional una ley que previera lo contrario y, lege data, que no habría recurso de amparo frente a una aplicación administrativa y judicial de ese plazo más largo previsto por norma posterior.

11 Naturalmente y hasta con más razón, igual prohibición de retroactividad rige para los reglamentos que en algunos ámbitos (como el de las ordenanzas locales o el de las normas de los colegios profesionales) tienen la posibilidad de tipificar infracciones más allá del marco general que ofrece el art. 27.3 LRJSP.

12 Sobre estas normas interpretativas o «aclaratorias» es de gran interés Villar Palasí (1972, pp. 459-478) que precisamente pone de relieve, además de la dificultad del concepto, que su utilidad ha sido históricamente en gran parte la de justificar su retroactividad, aunque dice, p. 471: «Ninguna disposición legal autoriza a que la vieja doctrina de la retroactividad ipso iure de la interpretación auténtica pueda mantenerse hoy». Más radicalmente Santamaría Pastor (1988, p. 378) afirma: «las normas aclaratorias o interpretativas simplemente no existen; son un falso concepto. Toda norma aclaratoria o interpretativa contiene un novum (...); es una norma complementaria o ejecutiva de la pretendidamente aclarada o interpretada, por lo que no hay ninguna razón para que su entrada en vigor se retrotraiga a la de ésta». Y advirtió López Menudo (1982, p. 167) que uno de los puntos de fuga de la irretroactividad de las normas sancionadoras desfavorables está en las «falsas normas aclaratorias e interpretativas». 
REALA. Nueva Época - N.o 16, octubre 2021 - ISSN: 1989-8975 - DOI: https://doi.org/10.24965/reala.i16.10961 - [Págs. 6-32]

Sucesión de normas administrativas sancionadoras: irretroactividad y excepciones

Manuel Rebollo Puig

el infractor que esas dudas interpretativas puedan comportar. Aplicación correcta de esta idea es la de la STS de 4 de marzo de $2016^{13}$ :

«No debe olvidarse que cuando se quiere dotar de carácter retroactivo a las normas interpretativas, en cuanto pretenden mantener su vigencia desde la fecha de vigencia de la norma interpretada, se incurre en un contrasentido, pues si la norma anterior ha necesitado de interpretación, ello implica reconocer que no era seguro el alcance de la norma anterior hasta que no fue interpretada. $Y$ este pretendido efecto retroactivo no puede servir como fundamento para sancionar una conducta anterior a dicha norma por entender que, conforme a la normativa anterior, debidamente interpretada a la luz de la norma posterior, ya era sancionable, pues ello implicaría conceder eficacia retroactiva de una norma sancionadora, posibilidad expresamente vedada en el art. 9.3 de la CE y 128 de la Ley 30/1992» (hoy art. 26 LRJSP).

Algo similar sucede con los criterios interpretativos desfavorables que acoja la jurisprudencia posterior a la acción enjuiciada. EI TEDH parte a este respecto de considerar que la jurisprudencia sobre las normas punitivas es fuente del Derecho y, como quiera que el artículo 7.1 del CEDH habla de «Derecho», no de ley, proclama la irretroactividad de los criterios judiciales desfavorables ${ }^{14}$. Igual conclusión se alcanza, aunque se niegue a la jurisprudencia naturaleza de fuente del Derecho ${ }^{15}$. Lo mismo mantiene el TJUE. Es expresiva su sentencia de 10 de junio de 2014, as. C-295/12 P, Telefónica c. Comisión, que, ante una infracción de abuso de posición dominante, dijo: «... los principios de legalidad de las penas y de seguridad jurídica (...) pueden oponerse a la aplicación retroactiva de una nueva interpretación de una norma que define una infracción (ap. 147); y «así ocurre, en particular, cuando se trata de una interpretación jurisprudencial cuyo resultado no era razonablemente previsible en el momento en que se cometió la infracción...» (ap. 148).

Idéntica solución puede extenderse a los criterios interpretativos que establezca la propia Administración. Y así lo hace el TS como muestra su sentencia de 27 de febrero de 2012 (rec. 747/2009) que, ante una sanción impuesta por la Agencia de Protección de Datos, dijo:

«... no es posible que la Agencia (...) considere cometida una infracción cuando la misma conducta había sido considerada impune en resoluciones anteriores, entendiendo que en materia sancionadora los nuevos criterios, por muy razonables que estos sean, ya estén contenidos en una norma o deriven de una decisión de la Administración interpretando las normas, han de desplegar sus efectos hacia el futuro pero nunca proyectarse hacia actuaciones pasadas que se acomodaran a los criterios entonces existentes, así como que la relación de los administrados con la Administración debe sustentarse en un principio de confianza legitima, confianza que solo puede generarse cuando se tiene previsibilidad y seguridad en la actuación de la Administración».

\subsection{Irretroactividad in peius de las normas no sancionadoras en cuanto se integran con las sancionadoras}

Ante normas que prevén castigo para una conducta tipificada total o parcialmente como la transgresión de otra norma no sancionadora (una norma que simplemente impone un deber, una prohibición, una limita-

13 Recurso 2163/2013. Los hechos eran estos: antes de 2010 Gas Natural denegó a 399 clientes el cambio de suministrador porque habían manifestado su voluntad de forma oral en grabaciones telefónicas; Gas Natural se escudaba en que en esa fecha podía interpretarse que el consentimiento verbal no bastaba; en 2010 se aprobó un reglamento que dejaba claro que el consentimiento verbal era suficiente; a partir de ese momento Gas Natural comunicó que atendería los cambios pedidos verbalmente. La Administración sancionó a Gas Natural por abuso de posición dominante por entender que ya antes de 2010 la manifestación verbal era suficiente y que el reglamento de 2010 sólo aclaraba lo que de todas formas se podía deducir con anterioridad. El TS, con el razonamiento transcrito en el texto, anuló la sanción. De otro lado, la STS de 17 de marzo de 2009 (rec. 4283/2006) ofrece un ejemplo en el que sí se entendió que la norma interpretativa era perfectamente conforme con la ley interpretada y con un criterio que pudo conocer la sancionada antes de su acción.

14 Por todas, STEDH (Gran Sala) de 21 de octubre de 2013, caso Del Rio Prada c. España, apdos. 91 a 93.

15 Afirma Muñoz Machado (2015, p. 207): «... la conclusión tiene que ser que la prohibición de retroactividad ha de concebirse como absoluta, se entienda o no que la jurisprudencia crea Derecho». Si se niega a la jurisprudencia carácter de fuente del Derecho, cabe decir, como hace Cano Campos (2018, p. 57), que no se trata propiamente de aplicar la prohibición de retroactividad in peius sino el principio de tipicidad o directamente el de seguridad jurídica «pues cuando se realiza la conducta se hace en la confianza de que el significado de la norma es el que la jurisprudencia viene aplicando, no el nuevo criterio que ahora adopta y que entonces era imprevisible». En igual dirección, Ruiz Antón (1991, pp. 165-167) que razona que la retroactividad de la jurisprudencia agravatoria, violaría la seguridad jurídica igual que si de un cambio legislativo in peius se tratara. 
ción), la prohibida retroactividad desfavorable debe extenderse a esta otra norma no sancionadora en cuanto a las consecuencias punitivas. El supuesto al que nos referimos puede identificarse con el de las llamadas normas sancionadoras en blanco, utilizado el concepto en sentido amplio (esto es, sea cual sea la forma en que la norma punitiva alude a la otra y sea esta otra del mismo o diferente rango y emanada del mismo órgano o de otro). Para los demás efectos - para los no punitivos- la norma no sancionadora podrá ser o no retroactiva según reglas distintas de las que aquí analizadas. Pero en cuanto a su integración con una norma punitiva debe regir la prohibición de retroactividad en la medida en que esa otra norma aumente el ámbito de la infracción punible (Gómez Tomillo y Sanz Rubiales, 2017, p. 198). Lo contrario supondría, no ya castigar lo que no era punible cuando se realizó, sino incluso lo que acaso no era siquiera ilícito. Por ejemplo, según la ley del medicamento, es infracción administrativa «dispensar medicamentos sin receta, cuando ésta resulte obligada». La norma requiere integrarse con las disposiciones que establecen los medicamentos que requieren receta. Si un sujeto expende sin receta el fármaco $X$ cuando esas disposiciones no la exigían para tal medicina, su conducta no podrá ser sancionada aunque con posterioridad se modifiquen e impongan la receta; sostener lo contrario sería, en realidad y con toda evidencia, vulnerar la prohibición de retroactividad in peius de las normas sancionadoras.

La STC 38/1997 explicitó lo aquí afirmado ante una nueva ley tributaria no sancionadora (alteró respecto al pasado la forma de cuantificar la deuda tributaria) que se integraba con una norma sancionadora anterior que no se había modificado. La sentencia dijo que esta nueva ley «está admitiendo la aplicación retroactiva de una disposición que, al constituir el complemento indispensable de las normas sancionadoras (...), participa también de este carácter a los efectos constitucionales»; y después: «es evidente que (...), en tanto que integra otra de carácter sancionador (...), que determina la sanción aplicable a las infracciones (...) supone la aplicación retroactiva de una norma de dicho carácter». En suma, la norma tributaria no sancionadora, en cuanto a su integración con otra sí sancionadora (no a los demás efectos), tiene la misma prohibición de retroactividad in peius ${ }^{16}$.

\subsection{Irretroactividad de la habilitación legal a reglamentos sancionadores}

La prohibición de retroactividad in peius de las normas punitivas es un límite a las convalidaciones legislativas; por tanto, no cabe que una ley convalide una sanción o un reglamento sancionador inválido (Boix Palop, 2004, pp. 270-273). Yendo algo más lejos, también se ha entendido proscrita la retroactividad de la habilitación de una ley a los reglamentos sancionadores aprobados antes de esa ley. Así lo hizo la STC 29/1989: se aprobó en 1983 sin habilitación legal un reglamento sancionador sobre tutela del consumidor (RD 1945/1983) y en 1984 la ley de defensa de los consumidores -que ya sí contenía una mínima regulación material de las infracciones y sanciones en ese sector-incluía una disposición final en la que declaraba que aquel reglamento previo era el desarrollo de la nueva regulación sancionadora legal. Frente a ello, el TC afirmó:

«... es obvio que esta Ley no podía prestar cobertura legal al RD 1945/1983 para la imposición de sanciones por infracciones cometidas con anterioridad a la vigencia de la propia ley, dada la irretroactividad de las disposiciones sancionadoras (art. 9.3 de la Constitución)» ${ }^{17}$.

Lo mismo reiteró ante una situación parecida la STC 45/1994, de 15 de febrero ${ }^{18}$. La prohibición de retroactividad desfavorable impide en estos casos que el reglamento se aplique a los hechos que se produjeron en el periodo que va desde la aprobación del reglamento hasta la aprobación de la ley ha-

16 El supuesto era algo peculiar porque se trataba de la ley que se dictó para superar la situación creada por otra STC anterior que declaró inconstitucional el régimen de tributación conjunta por IRPF de los matrimonios. Esa especie de ley-puente para superar la situación creada no cambió la tipificación de infracciones ni la previsión de las sanciones, pero sí cambió para periodos previos a su aprobación el modo de calcular la deuda tributaria. Además, en este caso el TC no anuló la ley en cuestión porque entendió que no era perjudicial sino favorable pues reducía la deuda tributaria. Pero al margen de todo eso, sí que dejó sentada la idea que aquí nos importa.

17 Sobre la inconstitucionalidad de ese RD 1945/1983 y sobre el intento de sanación por la ley posterior, vid. Rebollo Puig (1989, pp. 504-519); así como Rebollo Puig (1992, pp. 1078-1085).

18 En este caso se trataba de un reglamento sobre infracciones de tráfico al que después una ley intentó dar fundamento legal. Pero el TC dijo que «no es posible aceptar que la cobertura legal ex post facto pueda subsanar el vicio previo causante de la vulneración del art. 25.1 CE».

Aparentemente en contra y sin fundamentación bastante, STS de 25 de mayo de 2004 (rec. 448/2002) que acepta una ordenanza sobre animales de compañía dictada en 1994 pues «hoy la misma en virtud de lo dispuesto en la Ley $57 / 2003$ (...) tiene plena cobertura legal, por adecuarse a las previsiones específicas de dicha ley». Vid. Rebollo Puig e Izquierdo Carrasco (2007, pp. 3739-3740). 
bilitante del reglamento. Pero no impide que aquel reglamento sea aplicable a los hechos posteriores a la ley habilitante. En mi opinión, esto también está prohibido, pero por otra regla distinta: el reglamento (cualquier reglamento, aunque no sea sancionador y desfavorable) que nació nulo por vulnerar la reserva de ley no puede ser subsanado por una ley posterior que le dé cobertura. A este respecto, cabe decir, el orden de los factores sí altera el producto: la habilitación legal a los reglamentos ha de ser anterior a esos reglamentos. Pero, insisto, esta consecuencia es ajena a la prohibición de retroactividad in peius que aquí nos ocupa.

\subsection{Exclusión de las normas procedimentales}

No son «disposiciones sancionadoras» de las que habla el artículo 26.1 LRJSP las que regulan el procedimiento sancionador. Con más razón quedan fuera las relativas a los recursos administrativos y contencioso-administrativos contra las resoluciones sancionadoras. Ninguna de ellas entra tampoco dentro del ámbito del artículo $25.1 \mathrm{CE}$ pues esas normas procedimentales y procesales ni tipifican infracciones ni prevén sanciones. Igualmente quedan extramuros de nuestra regla las normas relativas a la competencia de los distintos órganos administrativos o judiciales para incoar, instruir y resolver los procedimientos sancionadores o para resolver los recursos contra sanciones. Por tanto, en suma, todas esas normas sobre los aspectos procedimentales y orgánicos no son a estos efectos normas sancionadoras ni rige para ellas la irretroactividad in peius de la que aquí nos ocupamos.

Algunos autores critican esa solución ${ }^{19}$. Tales críticas se superan con esta aclaración: las normas procedimentales no se ven afectadas por la prohibición de la retroactividad in peius de las normas punitivas; pero sí quedan sometidas a otras reglas distintas que imponen cierta irretroactividad que es por completo diferente en su fundamento material, ámbito y significado. También tiene distinto apoyo constitucional (quizá el art. 9.3 CE cuando proclama la irretroactividad de las disposiciones «restrictivas de derechos individuales») y legal (art. 2 de la Ley de Enjuiciamiento Civil: «... normas procesales vigentes, que nunca serán retroactivas»). Lo que más evidencia que la irretroactividad de las normas procesales es totalmente diversa de las de las normas punitivas es que jamás ha significado que los hechos hayan de juzgarse conforme a las reglas vigentes en el momento de cometerse los hechos enjuiciados, esto es, la infracción de que se acusa (que es lo que se predica de las normas punitivas) y no conforme a las posteriores ${ }^{20}$. Lo que si acaso se acepta es que deban aplicarse las normas procedimentales vigentes en el momento de inicio del proceso y no las posteriores a ese momento que resulten desfavorables ${ }^{21}$.

Por lo demás, en cuanto a esa otra retroactividad (la de la regulación del procedimiento administrativo sancionador), lo que ha abordado la jurisprudencia es la de las normas que alargan el tiempo para su tramitación y que, por tanto, retrasan su caducidad perjudicando de esa forma al imputado. Y lo han hecho sin criterios uniformes ${ }^{22}$. Pero, reitero, eso no tiene nada que ver con lo que aquí nos incumbe y, por tanto, debe abordarse con principios distintos del de la irretroactividad de las normas punitivas.

19 Así, López Menudo (1982, pp. 172-176), hasta concluir que tal tesis «podrá regir para procedimientos de otra índole, pero es inadmisible en relación con los sancionadores. En estos debe respetarse el régimen bajo el cual fuera cometida la infracción (...) Sólo en el caso de que las normas de procedimiento posteriores fueran más favorables podrían ser aplicadas...». Reiteró sus argumentos y conclusiones en Lozano Cutanda (2010, p. 726). En similar dirección, Cano Campos (2018, pp. 56-57), y Cano Campos (2014, p. 139).

20 Gómez Orbaneja y Herce Quemada (1987, p. 28): «Ningún tribunal puede proceder sino a tenor de la ley procesal vigente en el momento del proceso, sin consideración a la que pudiera regir en el momento de la perpetración del delito».

21 Una prueba de fuego es lo que sucede con la prisión provisional, por ser medida procesal extremadamente restrictiva y similar a las penas. Y ante ello el TC, con toda razón, no aplica de ningún modo la regla de la irretroactividad de las normas punitivas. Su doctrina quedó sentada en las SSTS 32 y 117/1987. Allí puso límite a la retroactividad de las nuevas normas desfavorables reguladoras de la prisión provisional pero un límite muy distinto del que rige respecto a las normas punitivas. Por lo pronto, no invocó el art. 25.1 CE. Cuando esgrimió el art. 9.3 CE lo hizo en cuanto se refiere a las normas restrictivas de derechos, no a las normas sancionadoras. Y además, lo que decidió fue que la ley aplicable era la vigente cuando comenzó la prisión provisional, de ningún modo la vigente cuando se cometieron los delitos enjuiciados, que sería lo que correspondería si se tratara de aplicar la regla de la irretroactividad de las normas punitivas.

22 Buena y clara solución ofrece la STS de 5 de junio de 2007 (rec. 7616/2003): al iniciarse un procedimiento sancionador en materia de aguas, regía una norma que establecía como plazo de duración el de seis meses; durante su tramitación y antes de que transcurrieran esos seis meses otra norma fijó el plazo en un año; la resolución se dictó y notificó después de los seis meses pero antes del año. Alegada vulneración de la prohibición de la retroactividad in peius de las normas sancionadoras, el TS entendió que no había tal vulneración porque "una norma procedimental no puede considerarse limitadora o restrictiva de derechos». Pero la situación es confusa y hay algunos pronunciamientos discrepantes relativos a procedimientos sancionadores tributarios (SSTS de 29 de diciembre de 2011, rec. 152/2009; y de 9 de abril de 2013, rec. 3943/2012). 


\subsection{Sobre las normas relativas a la ejecución de las sanciones}

Puede que la reforma legal afecte no al castigo sino a la ejecución de la sanción: que se adelante su ejecutividad; que se establezcan nuevas formas de ejecución forzosa (por ejemplo, multas coercitivas o compulsión sobre las personas); que se acorten los plazos de cumplimiento voluntario o se alarguen los de la posible ejecución forzosa; etc. Por lo general, dado que esas normas no son propiamente sancionadoras, no sufren la prohibición de retroactividad desfavorable aquí analizada. Es del todo lógico que lo concerniente a la ejecución de un acto administrativo se rija por la norma vigente en el momento de dictarse; si acaso, por el del momento en que se inició el procedimiento que con él culminó; de ningún modo que sea aplicable la norma que regulaba esos aspectos cuando se cometió la infracción sancionada. Dicho de otra forma, que a este respecto no es de aplicación la irretroactividad de las normas punitivas in peius; si acaso, podrá invocarse alguna otra regla que limite la retroactividad, pero no la de las normas punitivas desfavorables.

Hay, sin embargo, que introducir un matiz relativo a la prescripción de las sanciones. La prescripción de las sanciones pudiera considerarse una cuestión de ejecución. A fin de cuentas, el plazo de prescripción de las sanciones señala el momento a partir del cual no cabrá ejecutarlas. Y como el artículo 26 LRJSP se refiere a la prescripción sin distinguir entre la de las infracciones y la de las sanciones; $y$, aunque lo hacen a los efectos de imponer la retroactividad in bonus, pueden inclinar a entender que, para los casos en que alarguen esos plazos, jugará la irretroactividad in peius. No me parece que sea una regla de rango constitucional ni que encuentre sustento en ningún tratado internacional de derechos humanos, pero sí puede encontrarlo en esos preceptos legales.

No creo, por el contrario, que la STEDH (Gran Sala) de 21 de octubre de 2013, caso Del Rio Prada c. España, obligue a introducir más correcciones. Es cierto que extendió la irretroactividad de las normas penales a una cuestión de ejecución de las penas como era la de la aplicación de la redención de penas por el trabajo en prisión y que por ello consideró contraria al artículo 7 CEDH la aplicación de la llamada «doctrina Parot» a una terrorista que cometió los múltiples asesinatos por los que estaba condenada antes de que el TS formulara tal doctrina. Pero, aun así, incluso esa sentencia reconoce la distinción entre normas sobre penas y normas sobre ejecución de las penas y admite que, en principio, la irretroactividad solo juega para aquéllas, no para éstas (apdos. 83 y 84). Sin entrar aquí en su discutida argumentación ni en sus nefastos efectos, nada de lo que afirma altera lo sostenido para las reglas sobre ejecución de las resoluciones administrativas sancionadoras. Los matices que introduce valen, si acaso, para la ejecución de algunas penas, no para la de las sanciones administrativas.

\subsection{Momento en que han de entenderse cometidas las infracciones a estos efectos}

Con ínfimas diferencias de redacción, tanto los tratados internacionales como la Constitución y la LRJSP, al proclamar la irretroactividad de las normas punitivas desfavorables, toman como referencia el momento en que la acción u omisión se cometió. Pero ¿cuál es ese momento? No se trata de determinar en abstracto en qué momento se ha cometido una infracción. Sólo de determinar ese momento a efectos de seleccionar la ley aplicable. De hecho, no cabe determinar un único momento de comisión a todos los efectos. Y así se acepta comúnmente en Derecho Penal que el momento en que debe entenderse cometido un delito puede y hasta a veces debe ser distinto según se trate de, por ejemplo, determinar si el sujeto era o no imputable, si esa infracción ha prescrito o no... ${ }^{23}$. Lo que aquí nos interesa es la determinación del momento de comisión a efectos de aplicar la irretroactividad in peius: si se decide que la infracción se cometió el día $\mathrm{D}$ y ese día ya estaba vigente la nueva norma, la aplicación de ésta no incurrirá en la retroactividad prohibida aunque el sujeto realizara antes de esa vigencia algunos actos relacionados con la infracción ${ }^{24}$.

La LRJSP nada dice sobre ese momento. Sí que da algunas reglas sobre el momento en que arranca el plazo de prescripción de la infracción (art. 30.2) lo que a su vez suele ponerse en relación con el momento de comisión. Pero, de acuerdo con lo recién señalado, esas reglas no pueden trasladarse simplistamente

23 Y lo mismo se afirma para las infracciones administrativas. Así, López Menudo (1982, p. 167).

24 Un ejemplo claro es el de la STS 946/2018, de 6 de junio, sobre la sucesión de las Leyes de Defensa de la Competencia de 1989 y de 2007: bajo la vigencia de la primera se tramitó un procedimiento sancionador contra la sociedad estatal Correos que finalizó por acuerdo de terminación convencional en 2005; Correos incumplió sus compromisos en 2008 y 2009 ; se le sancionó en aplicación de la nueva Ley de 2007; frente a ello, Correos alegó que se le estaba aplicando retroactivamente esa Ley de 2007 y que se debía aplicar la Ley de 1989 que no tipificaba como infracción el incumplimiento de los acuerdos de terminación convencional. Con acierto, la STS reseñada afirmó que «para determinar la norma aplicable lo relevante no es la norma que estaba vigente cuando se adoptó el Acuerdo de Terminación Convencional sino la Ley vigente cuando tuvo lugar la conducta infractora». 
REALA. Nueva Época - N.o 16, octubre 2021 - ISSN: 1989-8975 - DOI: https://doi.org/10.24965/reala.i16.10961 - [Págs. 6-32]

Sucesión de normas administrativas sancionadoras: irretroactividad y excepciones

Manuel Rebollo Puig

a efectos de determinar el momento de comisión de la infracción que debe tomarse en consideración para elegir la norma aplicable.

Sí hay una respuesta en el artículo $7 \mathrm{CP}$ : acoge el criterio de la actividad y excluye el del resultado. Este mismo criterio de la actividad hay que asumir para las infracciones administrativas. No por aplicación de un precepto del CP, lo que no tiene justificación, sino porque esa solución es, en realidad, la que se ajusta al sentido de la irretroactividad de las normas sancionadoras desfavorables ${ }^{25}$. Tan es así, que ese criterio de la actividad era el asumido unánimemente antes de que se explicitara en el $\mathrm{CP}^{26}$.

Ahora bien, el criterio de la actividad no da respuesta para los muchos casos en que la actividad (o la omisión) infractora no es instantánea, sino que se realiza a lo largo del tiempo (Gallardo Castillo, 2008, pp. 149151). Entonces, si durante ese tiempo ha habido cambio perjudicial de las normas sancionadoras, hay que decidir qué concreto momento de ese periodo hay que elegir ¿el del primer acto, el del último, alguno intermedio?

La respuesta no es fácil. No lo es siempre en Derecho Penal y menos lo es en el Derecho Administrativo sancionador ${ }^{27}$ en el que, a veces, dado que con frecuencia los tipos están descritos con brocha gorda, ni siquiera es sencillo discernir si se trata de infracciones de acción u omisión, si son permanentes, de hábito... Ofreceré, con apoyo en la jurisprudencia contencioso-administrativa, algunas respuestas concretas.

Ante las infracciones permanentes, si se siguen realizando bajo la vigencia de la nueva norma más severa se puede aplicar ésta sin que ello suponga incurrir en la retroactividad prohibida pese a que la infracción se comenzó, se realizó parcialmente y hasta se consumó (aunque no se agotó) bajo la vigencia de la más benigna ${ }^{28}$.

Para las infracciones de omisión es razonable aplicar la misma solución que en general se acepta para los delitos de omisión: si es de omisión pura, lo decisivo es el último momento en que el sujeto pudo realizar tempestiva y oportunamente la acción exigida y cumplir su deber; si es de comisión por omisión, lo decisivo es el último momento en que el sujeto pudo evitar el resultado prohibido (González Tapia, 2002, pp. 285286). Por tanto, si la nueva ley más severa estaba vigente en ese último momento, su aplicación no incurrirá en la proscrita retroactividad desfavorable.

En cuanto a las infracciones continuadas ${ }^{29}$, hay que partir de que, en realidad, hay distintas infracciones (es un caso de concurso real de infracciones), como explica Alarcón Sotomayor (2008, pp. 67-68), aunque por razones de proporcionalidad y simplificación se opte por sancionarlas conjuntamente. Con esa premisa, hay que abordar las tres hipótesis posibles. Primero, si lo que ha hecho la nueva ley es tipificar como infracción lo que antes era impune, la solución es obvia: habrá que sancionar solo las acciones posteriores a esa ley; las anteriores no podrán castigarse de ningún modo (tampoco integrándolas con las posteriores a la ley para formar con ellas la infracción continuada). Segundo, si estando ya tipificada la infracción la nueva ley agrava la sanción, a las realizadas antes de la nueva ley hay que aplicarles la ley previa; y sólo a las posteriores la nueva ley más severa ${ }^{30}$. Por tanto, hay que desintegrar la infracción continuada. Así, claro está, no

25 Es más, si se atendiera al momento del resultado, como explica González Tapia (2002, p. 114), el sujeto se vería sorprendido por aplicación de una ley que no pudo conocer cuando actuó de suerte que se «frustrarían los fines que justifican el principio de irretroactividad», esto es, sobre todo la seguridad jurídica.

26 Hasta el punto de que muchos autores (como Cobo Del Rosal, González Rus o Vives Antón) lo consideran un precepto superfluo, como explica González Tapia (2002, pp. 128 y 239).

27 Como afirmó López Menudo (1982, p. 169), las dificultades crecen «porque la propia tosquedad de los tipos administrativos debe impedir su análisis desde perspectivas jurídicas exquisitas que el legislador (...) administrativo quizás no tuvo en cuenta».

28 Dos ejemplos serán suficientes. La STS de 17 de abril de 2002 (rec. 466/2000) se ocupó de una infracción consistente en la actuación de una jueza en un proceso con vulneración de su deber de abstención. La sancionada alegó que cuando comenzó con su conducta no estaba vigente el art. 417.8 LOPJ, que es el que tipifica como falta muy grave «la inobservancia del deber de abstención a sabiendas de que concurre alguna de las causas legalmente previstas». La sentencia, sin embargo, niega que se hubiera incurrido en la retroactividad desfavorable prohibida puesto que la jueza continuó con la instrucción hasta que fue suspendida en el ejercicio de sus funciones cuando ya estaba vigente la norma en cuestión. Por tanto, se cometió la infracción cuando la conducta ya estaba tipificada como infracción muy grave y no hubo aplicación retroactiva de la norma sancionadora desfavorable. La SAN de 16 de septiembre de 2008 (rec. $488 / 2006$ ) desechó también la vulneración del principio de irretroactividad de las normas sancionadoras desfavorables ante un supuesto de funcionamiento de una emisora de radio sin autorización que se sancionó en virtud de la Ley 32/2003 General de Telecomunicaciones. Se alegó que la emisora funcionaba con anterioridad y que en el momento de su instalación la ley a la sazón vigente (Ley 31/1987, de Ordenación de las Telecomunicaciones) no exigía autorización. La sentencia confirmó la sanción porque la conducta se había mantenido ya estando vigente la nueva ley y, desde entonces, había devenido típica. No se sanciona por lo acontecido antes de la Ley 32/2003 sino por lo que se continuó realizando sin autorización tras ella. Por tanto, tampoco en este caso hubo aplicación retroactiva de la norma sancionadora desfavorable.

29 Sobre el tratamiento de los delitos continuados, González Tapia (2002, 294 y ss.), cuyas propuestas son aquí tenidas en cuenta con adaptaciones.

30 No se adecua a ello la SAN 522/2020, de 7 de enero (RJCAl20201254). Varias personas fueron sancionadas por infracciones de pesca. Las primeras infracciones se cometieron bajo la vigencia de un determinado régimen sancionador pero las últimas se cometieron cuando ya había entrado en vigor otro (establecido por la Ley 33/2014) que endurecía las sanciones máximas que cabía 
se vulnera la prohibición de retroactividad in peius ${ }^{31}$. Y, tercero, si lo que hace la nueva norma es alargar el plazo de prescripción, lo razonable es que en tal hipótesis se descomponga la infracción continuada y que todas las realizadas antes de la nueva norma prescriban con el régimen de la norma anterior más favorable ${ }^{32}$.

Problemas singulares plantean las infracciones, frecuentes en el ámbito disciplinario, consistentes en «la condena en virtud de sentencia firme por delito» ¿Cuándo ha de entenderse cometida la infracción? ¿en el momento en que se cometió el delito o en aquel otro en que recayó la condena penal firme? La respuesta más adecuada al fundamento y sentido de la prohibición de retroactividad in peius es la de tomar en consideración el momento de comisión del delito, que es cuando el sujeto actuó. Pero el TS ha entendido que ha de estarse al momento de la condena penal ${ }^{33}$; con ello, en realidad, el sujeto se ve sorprendido por una ley que no pudo conocer cuando actuó.

Con carácter general creo de aplicación, como también se ha propuesto en Derecho Penal, el in dubio pro reo de modo que se opte por situar la infracción en el momento que impida toda retroacción desfavorable incluso a infracciones que en gran parte, pero no totalmente, se cometieron ya bajo la vigencia de la nueva norma más severa.

\subsection{Consecuencias de la vulneración de la regla y cauces para eliminarla}

Hay que distinguir según se vulnere la regla en cuanto prohibición al legislador y en cuanto prohibición al aplicador de la norma, la Administración.

La norma sancionadora desfavorable que proclame su aplicación retroactiva es nula por inconstitucional (es contraria no solo al art. 9.3 CE sino también al art. 25.1). Y frente a ella se abren las vías previstas contra las normas inconstitucionales: recurso (o cuestión) de inconstitucionalidad y recurso contencioso-administrativo según se trate de ley o de reglamento.

Las resoluciones administrativas que apliquen retroactivamente una norma sancionadora desfavorable son nulas de pleno derecho. Como lesionan un derecho susceptible de amparo constitucional (uno de los derechos incluidos en el art. 25.1 CE) están incursas en la causa de nulidad del artículo 47.1.a) LPAC. Frente a ellas sirven todos los medios previstos contra los actos administrativos ilegales. Y, además, servirán los cauces de protección reforzada establecida para los derechos fundamentales: recurso de amparo ante el TC y recurso contencioso-administrativo especial de protección de los derechos fundamentales (arts. 114 y ss. LJCA ${ }^{34}$. Si eventualmente la Administración hubiera aplicado retroactivamente una ley sancionadora desfavorable porque la misma ley así lo estableciera, entonces el juez contencioso-administrativo, antes de anular la resolución sancionadora, deberá plantear cuestión de inconstitucionalidad. De otra parte, por ser nulas de pleno derecho las resoluciones que aplique retroactivamente una norma punitiva desfavorable,

imponer (pasaban de 300.000 a 600.000 euros). La Administración calculó el importe de las multas de acuerdo con la nueva ley. Los sancionados impugnaron alegando violación del principio de irretroactividad y, específicamente, de la disposición transitoria $1^{\text {a }}$ de la nueva ley, a cuyo tenor «las infracciones cometidas con anterioridad a la entrada en vigor de esta ley serán objeto de la sanción que resulte más favorable para el infractor». Pero la SAN entendió que «nos encontramos ante infracciones continuadas (...) por lo que en definitiva, las conductas infractoras por las que han sido sancionados los recurrentes no habían cesado en la fecha de entrada en vigor de la modificación de la Ley de Pesca Marítima del Estado por Ley 33/2014, de 26 de diciembre (...), por lo que no resulta de aplicación la disposición transitoria $1 .^{a}$ de tal Ley $33 / 2014$ (...) pues no se trata de infracciones cometidas con anterioridad a la entrada en vigor de la modificación de la Ley de Pesca de 2014, sino que han continuado cometiéndose con posterioridad».

31 El problema estará en que, precisamente por la sucesión de normas, el infractor se vería perjudicado al descomponerse en dos infracciones continuadas lo que podría haberse considerado una sola. Ante ello, al margen de la irretroactividad, lo correcto será simplemente moderar la suma de las dos sanciones pertinentes (la de las infracciones continuadas anteriores y posteriores a la nueva ley) para que la impuesta resulte adecuada a la gravedad de la conducta en su conjunto. Una forma de hacerlo, entre otras, será aplicar al conjunto la ley más favorable, aunque no estuviese vigente cuando se realizaron parte de las infracciones. Pero esto no será ya problema de retroactividad sino únicamente de proporcionalidad.

32 Por eso me parece errónea la STS 1776/2020, de 17 de diciembre, que ante una infracción continuada contra la competencia realizada durante veintisiete años y bajo la vigencia de tres sucesivas leyes sobe competencia (de 1963, de 1989 y de 2007 ) aplica a todas el régimen previsto en la última de ellas que suponía un plazo de prescripción mucho más largo que la de la primera ley. Si realmente se trataba de infracciones continuadas (y no de infracción permanente), la solución de la sentencia supone aplicar retroactivamente una norma desfavorable a todas las infracciones cometidas íntegramente bajo la vigencia de la ley de 1963.

33 Así, STS, Sala de lo Militar, de 12 de mayo de 2011 (recurso 11/2011). Entendió que había que considerar cometida la infracción administrativa con la sentencia penal. Esto le permitió afirmar que la ley disciplinaria desfavorable no se había aplicado retroactivamente porque ya estaba vigente cuando recayó la condena penal, aunque no lo estaba cuando el sujeto cometió el delito.

34 Acaso hay que exceptuar los casos en que la norma posterior acorte el plazo de prescripción porque las SSTS $73 / 1989$ y 196/1991 declararon que la apreciación de la prescripción de delitos e infracciones administrativas es cuestión de legalidad ordinaria sin relevancia constitucional. 
cabrá también contra ellas en cualquier momento la revisión de oficio (art. 106 LPAC). Asimismo, en cuanto consagrado en el artículo 7.1 Convenio Europeo de Derechos Humanos, goza de la protección que dispensa el Tribunal Europeo de Derechos Humanos.

Es dudoso si al anular una resolución sancionadora por haber aplicado una norma posterior desfavorable cabe, además del pronunciamiento anulatorio y cuando en virtud de la ley anterior procediese una sanción menos grave, imponer directamente esta otra sanción. En algún caso los tribunales han optado por esto último ${ }^{35}$. Con más razón puede procederse así cuando sea la misma Administración la que proceda a anular la sanción al resolver un recurso o una revisión de oficio. Pero, en el contencioso-administrativo, en general, salvo que la pretensión del sancionado recurrente sea exactamente esa reducción de la sanción, resulta más correcto que el fallo sea simplemente anulatorio y que la Administración, después, en su caso y con audiencia del interesado, decida la sanción procedente, decisión administrativa que podría controlarse en ejecución de la sentencia ${ }^{36}$.

\section{LA OBLIGADA RETROACTIVIDAD DE LAS NORMAS SANCIONADORAS FAVORABLES}

\subsection{Fundamento}

Es discutible que la Constitución establezca la obligatoriedad de esta retroactividad in bonus ${ }^{37}$. Indudablemente la permite. Pero que la permita no quiere decir que la imponga.

Ante ello se ha mantenido que la obligatoria retroactividad de las normas punitivas favorables no tiene fundamento constitucional de modo que, según esta tesis, la ley que introduzca una regulación menos severa es libre de establecer que las acciones cometidas bajo la vigencia de la ley anterior deban seguir siendo sancionadas conforme a esa ley previa ${ }^{38}$. El fundamento sería exclusivamente legal: el que le presta el artículo 2.2 CP y, en nuestro ámbito, el que le da el artículo 26.2 LRJSP. Si así fuese, otra ley podría excluir esa retroactividad ${ }^{39}$. Esta tesis que niega fundamento supralegal a la obligada retroactividad in melius tiene muchos aspectos positivos pues permite evitar los resultados inadecuados a que, según creo, conduce a veces la retroactividad de la norma posterior más benigna ${ }^{40}$. Además, está extendida en el Derecho comparado ${ }^{41}$.

35 Así, STSJ de la Comunidad Valenciana de 6 de marzo de 2002 (apelación 280/2001) que, en aplicación de la ley anterior y no la posterior invocada por la resolución administrativa recurrida, falló anular la multa de 600.000 ptas. e imponer la de 150.000 ptas.

36 Téngase en cuenta que incluso es posible que lo que proceda en virtud de la ley anterior sea, no una sanción administrativa, sino la imposición judicial de una pena (por ejemplo, la correspondiente a una de las faltas del CP convertidas en infracciones administrativas por el juego conjunto de las Leyes Orgánicas 1 y 4/2015). En esta hipótesis ni siquiera es concebible que el juez contenciosoadministrativo imponga la pena; menos todavía que lo haga la Administración. Sus pronunciamientos deberán ser solo anulatorios de la sanción sin perjuicio, en su caso, de la decisión del juez penal.

37 Hubo una enmienda al art. 9.3 CE que propuso añadir que «las leyes penales tendrán carácter retroactivo en cuanto favorezcan al reo», pero no prosperó. Vid. López Menudo (1982, p. 140).

38 Destacado valedor de esta tesis es López Menudo (1982, pp. 146-147 y 179-194). La asumen también: Nieto García (2012, pp. 202 y ss.); Santamaría Pastor (1988, p. 375); Caballero Sánchez (2001, p. 132) y Cano Campos (2018, pp. 57-58). Conste que quienes asumen esta tesis no lo hacen únicamente por entender que la retroactividad favorable no se desprende de los arts. 9.3 y 25.1 CE sino también por razones de fondo, porque entienden que es una regla que conduce en ocasiones a resultados injustificables. Revelador es López Menudo (1982, p. 191), cuando, recogiendo ideas de Quintano Ripollés, afirma que «el surgimiento de una norma más benigna no comporta necesariamente, en Derecho Administrativo, una disminución de la reprochabilidad de las conductas anteriores» y no expresa «un cambio valorativo sobre la gravedad de los hechos». Una idea similar será la que acogeremos aquí para, sin negar el rango supralegal de la retroactividad in bonus, reducir su ámbito.

39 Como la LRJSP es una norma básica dictada en virtud del art. 149.1.18. ${ }^{\text {a }}$ CE, cabría sostener que no cualquier ley podría contradecir su art. 26.2. No podrían hacerlo las leyes autonómicas; por ejemplo, una sobre infracciones urbanísticas no podrían establecer que, aunque su régimen sancionador sea más favorable que el de la ley previa, no se aplicará a hechos anteriores: si no inconstitucionalidad inmediata (pues estamos partiendo de que la obligada retroactividad in bonus no estuviese constitucionalizada) sí que estaría incursa en inconstitucionalidad mediata (por vulneración de una norma estatal básica, el art. 26.2 LRJSP). Pero el Estado al aprobar leyes no está vinculado por sus propias normas básicas para las que puede establecer excepciones (aunque algunos autores han defendido lo contrario, tal tesis no ha sido acogida por el TC). Por tanto, una ley estatal sobre, por ejemplo, sanciones de tráfico sí que podría establecer una excepción al art. 26.2 LRJSP.

40 Se verán luego esos resultados inconvenientes a los que conduce un inexorable y absoluto mandato de retroactividad favorable. Y, aunque en otras ocasiones la retroactividad in bonus sí que es muy razonable, cabría sostener que en esos casos la no retroactividad de las normas sancionadoras favorables sería inconstitucional, pero por vulneración de otras reglas, como la prohibición de arbitrariedad. Así, la regla sería más dúctil y permitiría ajustarla mejor a la justicia material que, como se expondrá de inmediato, es la justificación sustantiva de la regla.

41 Tanto el Tribunal Supremo de los Estados Unidos como el Tribunal Constitucional alemán y la Corte Constitucional italiana han entendido que sus respectivas Constituciones permiten, pero no imponen la retroactividad de las normas penales favorables. 
El escollo, y no es pequeño, es que chirría con el artículo 15.1 del Pacto Internacional de Derechos Civiles y Políticos que sí que proclama expresa e inequívocamente la imperativa retroactividad favorable («Si con posterioridad a la comisión del delito la ley dispone la imposición de una pena más leve, el delincuente se beneficiará de ello»), como lo hace también el artículo 49.1 in fine de la Carta de Derechos Fundamentales de la Unión Europea («Si con posterioridad a esta infracción la ley dispone una pena más leve, deberá aplicarse ésta»), lo que tiene para nuestro Derecho un valor reforzado a tenor del artículo 10.1 CE. Además, el TJUE lo considera un principio general del Derecho de la Unión ${ }^{42}$

Sea como fuere, no ha sido ésa la solución del TC. Para éste, por el contrario, nuestra regla sí tiene fundamento constitucional. La encuentra en el artículo 9.3 CE, aunque no en su artículo 25.1. Lo afirmó ya en la STC 8/1981:

«El problema de la retroactividad e irretroactividad de la Ley penal (en realidad no sólo de ella, sino también de otras disposiciones sancionadoras, aunque sólo a aquélla y no a todas éstas van dirigidas las consideraciones presentes) viene regulado por nuestra Constitución en su artículo 9.3, donde se garantiza la irretroactividad de las "disposiciones sancionadoras no favorables o restrictivas de derechos individuales". Interpretando a contrario sensu este precepto puede entenderse que la Constitución garantiza también la retroactividad de la Ley penal favorable (...) Pero del análisis del artículo 25.1 no se infiere que este precepto reconozca a los ciudadanos un derecho fundamental a la aplicación retroactiva de una Ley penal más favorable que la anteriormente vigente».

Aunque la argumentación es endeble ${ }^{43}$, el TC mantiene hasta hoy la misma conclusión, tanto para normas penales como sancionadoras administrativas ${ }^{44}$, y ello pese a que algunos magistrados hayan discrepa$\mathrm{do}^{45}$. Pero lo importante es que sí que da rango constitucional al mandato de retroactividad de las normas punitivas favorables. Desde este punto de vista, el que no lo encuentre en el artículo 25.1 es intrascendente: supone negar que esté en juego un derecho fundamental; pero, aun así, da rango y fundamento constitucional a la regla y, por tanto, excluye que el legislador pueda eludirla ${ }^{46}$.

Con este fundamento positivo supralegal, la retroactividad in bonus despliega sus efectos como mandato a las leyes ( $\mathrm{y}$ a los reglamentos en la modesta medida en que pueden ser fuente del Derecho Administrativo sancionador) y como mandato a los órganos administrativos encargados de su aplicación, así como a los jueces en cuanto controlen los actos administrativos sancionadores.

Vid. Lascuaraín Sánchez (2000, p. 56, nota). Lo mismo en Francia. Vid. Cano Campos (2014, p. 143, nota). Concretamente en Italia, no solo se viene negando que la regla tenga rango constitucional para las normas sancionadoras administrativas, sino que ni siquiera está consagrada con carácter general en la Ley 689 de 24 de noviembre de 1981 sobre sanciones administrativas que sólo proclama la prohibición de retroactividad desfavorable (art. 1.1) y una específica retroactividad in bonus para los casos en que esa misma ley convirtió en infracción administrativa lo que antes era delito (art. 40). Y, ante ello, la jurisprudencia ha negado su aplicación salvo que la establezca expresamente la nueva norma favorable. Vid. Cerbo (1999, pp. 49-56); Pagliari (2012, pp. 25-30); y Cimini (2017, pp. 241-243). No obstante, este último autor, ibídem, pp. 243-253, apunta que, atendiendo al art. 49.1 CDFUE y a la jurisprudencial del TEDH y del TJUE, es previsible una evolución en Italia que refuerce la retroactividad in bonus en el ámbito de las sanciones administrativas.

42 Así lo proclama en su sentencia de 30 de abril de 2020, Grecia c. Comisión, as. C-797/18 P., apdo. 157. Lo que resulta más extraño y discutible es que la génesis de ese principio general del Derecho de la Unión esté en la afirmación por parte del mismo TJUE de que «el principio de aplicación retroactiva de la pena más leve forma parte de las tradiciones constitucionales comunes de los Estados miembros (...) cuyo respeto garantiza el Tribunal de Justicia y que el juez nacional debe respetar». En ese sentido apdo. 32 de su sentencia de 8 de marzo de 2007, Campina, as. C-45/06; y en parecidos términos apdo. 59 de la de 11 de marzo de 2008, Jager, as. C-420/06; apdos. 68 y 69 de la de 3 de mayo de 2005, Berlusconi, as. C-387, 391 y 403/02. Pero, como se ha visto en nota anterior, son varios y de mucho peso los Estados de la Unión en los que la retroactividad de la norma punitiva más leve está lejos de formar parte de sus tradiciones constitucionales.

43 Por un lado, en cuanto a la deducción del art. 9.3 de la Constitución, es ilógico inferir de una regla prohibitiva que todo lo no prohibido es obligatorio. Sobre ello, López Menudo (1982, pp. 146-147 y 180-181) y en cuanto a la no deducción del art. 25.1 y a la negación del derecho fundamental, al menos choca, como ya se ha visto, con el artículo 15.1 del Pacto Internacional de Derechos Civiles y Políticos.

${ }_{44}$ Así en las SSTC 15/1981, 62/1982, 51/1985, 131/1986, 22/1990, 177/1994, 38/1997, 99/2000, 75/2002, 85/2006.. y en AATC 470/1994, 226/1990, 339/1992, entre otras. Entre las del TS en igual sentido sentencias de 8 y 15 de febrero de 2010 (recursos $4235 / 2006$ y n. $\left.{ }^{\circ} 6422 / 2004\right)$

45 Me refiero a los interesantes votos discrepantes de Mendizabal Allende a las SSTC 177 y 203/1994 y 99/2000, así como al de Cruz Villalón a la segunda de esas sentencias. Todos ellos en el sentido de considerar que el mandato de retroactividad favorable sí que encuentra apoyo en el art. 25.1 CE.

46 Es «exigencia constitucional, aunque no iusfundamental», según la expresión de Rodríguez Santiago (2019, p. 59). 
Como fundamento material no se esgrime el principio de seguridad jurídica que, según dije, sustenta la prohibición de retroactividad in peius ${ }^{47}$. En su lugar como justificación de la retroactividad favorable se invocan con acierto razones de justicia material ${ }^{48}$. A veces se busca su fundamento en el principio de proporcionalidad ${ }^{49}$. Pero, según creo, es más exacto decir que lo que se vulnera al no aplicar la ley posterior favorable es la justicia material que incluye, entre otras cosas, la proporcionalidad del castigo.

\subsection{Elementos de las normas sancionadoras con obligada retroactividad in bonus}

El artículo 26.2 LRJSP concreta los aspectos sobre los que ha de proyectarse la retroactividad favorable de las normas sancionadoras: "... tanto en lo referido a la tipificación de la infracción como a la sanción y a sus plazos de prescripción...». De acuerdo con ello, será necesariamente de aplicación la norma posterior que:

a) Destipifique una conducta; esto es, la norma que establezca que una acción que hasta su entrada en vigor y cuando se cometieron los hechos era constitutiva de infracción punible deja de serlo. Es posible que pase a ser una conducta lícita. Pero también cabe que siga siendo considerada antijurídica y para la que, incluso, se prevean consecuencias aflictivas pero no punitivas. En ambos casos, las destipificación debe comportar, según la regla analizada, que no cabrá imponer sanción. Esto puede presentarse con formas diversas: se destipifica toda la acción o solo la tentativa o la comisión culposa o se reducen los sujetos responsables... En principio, cabe asimilar a estos efectos la aparición de nuevas eximentes; sobre todo, una nueva causa de justificación ${ }^{50}$.

b) Disminuya el castigo que la norma anterior preveía para la conducta de que se trate. En principio es indiferente que se pase de pena (judicial) a sanción (administrativa); o sea, que el hecho pase de estar tipificado como delito (o, antes, falta) y pase a estarlo como infracción administrativa o que, como es más habitual, la acción siga dentro del orden penal o dentro del orden administrativo: lo importante es que el castigo previsto (lo impongan los jueces o la Administración) sea menor. Es irrelevante la forma en que se consiga esta disminución: la directa y genérica previsión de una sanción menor (por su naturaleza o por su extensión), la forma de calcular las multas ${ }^{51}$, la previsión de una nueva atenuante, la desaparición de una anterior agravante ${ }^{52} \ldots$ Todo lo que entrañe una reducción del castigo

47 Lascuaraín Sánchez (2000, p. 25): «La aplicación de una ley posterior favorable (...) no es una opción demandada por el valor de la seguridad jurídica ni por el principio de legalidad que lo encarna». Expresivamente dice Cano Campos (2018, p. 141): «la retroactividad in bonus no es el reverso de la retroactividad in peius, sino una figura distinta que tiene un fundamento diferente».

48 Rodriguez Mourullo (1997, pp. 133-134) lo expresa radical y certeramente: «Aunque con frecuencia se invocan razones humanitarias, la retroactividad de la ley más benigna posee un fundamento de justicia. La modificación de la ley es signo de un cambio valorativo operado en el ordenamiento (...) manifiesta el legislador una revisión de su primitiva concepción. Mantener a ultranza la irretroactividad equivaldría a condenar al autor de acuerdo con una concepción más severa que el propio ordenamiento jurídico repudió y la ley ya no profesa. Se vulneraría, en definitiva, la justicia material». En los votos particulares de Mendizábal Allende a las SSTC 177 y 203/1994 se explica jugosamente, en la misma línea, que la retroactividad benigna no obedece a «compasión humanitatis causa, ni tampoco por virtud del principio in dubio pro reo, sino por razones de Justicia, como valor constitucional preferente y norte del Estado de Derecho (...) Non pietatis sed iustitiae causa...». Defiende razones de mera humanidad, como un sector de la doctrina penal, López Menudo (1982, pp. 189 y ss). En contra de la justificación en razones de justicia material se dice con frecuencia que de ser así también habría que aplicar la ley posterior desfavorable. Pero aquí se trata de un equilibrio entre justicia y seguridad jurídica que, ante la norma desfavorable posterior, se decanta por la seguridad.

49 Lascuaraín Sánchez (2000, pp. 37 y ss).

50 Esto se puede producir con relativa frecuencia por modificación de normas distintas de la punitiva pero que aportan elementos para considerar que la conducta, aunque sigue siendo típica, ya no es antijurídica ni, por ende, punible. En materia de defensa de la competencia, podría tratarse de la aprobación de uno de los reglamentos aludidos en el art. 1.4 y 5 o de una de las leyes a que se refiere el art. 4.1 de la Ley de Defensa de la competencia. Expresivo ejemplo de esta aplicación de la retroactividad in bonus aporta la STS de 10 de junio de 2004 (rec. 433/1999) que anuló la sanción impuesta por infracción contra la competencia (se exigía al comprador de fotocopiadoras que firmase un contrato de asistencia técnica con la vendedora) porque mucho después se aprobó un reglamento que excepcionalmente permitía esa conducta.

51 Por ejemplo, las SSTS de 25 de febrero y 4 de marzo de 2009 (rec. 232 y 3943/2006) ante la modificación de la legislación de telecomunicaciones: en la ley vigente cuando se cometieron las infracciones había que calcular la multa en función de los ingresos brutos de la infractora mientras que en la ley posterior había que tener en cuenta sólo los ingresos obtenidos en la concreta rama de actividad en la que se había realizado la infracción; como la nueva norma comportaba una multa menor, ambas sentencias impusieron la aplicación retroactiva de ésta. La STS de 24 de julio de 2003 (rec. 11461/1998) valoró que la ley posterior preveía una reducción de la multa por conformidad con la regularización tributaria.

52 Así, STS de 30 de junio de 2010 (rec. 2848/2005) ante la desaparición en la Ley General Tributaria de 2003 de la agravante de «comisión repetida de infracciones tributarias» y su sustitución por la de haber sido sancionado «por una infracción de la misma naturaleza». 
habrá de aplicarse retroactivamente ${ }^{53}$. Por el contrario, lo que concierna a consecuencias aflictivas, pero no punitivas de ilícitos queda al margen de esta obligada retroactividad in bonus ${ }^{54}$.

c) Acorte el plazo de prescripción (o adelante el momento en que empieza a correr o suprima alguna causa de interrupción) $)^{55}$. Aunque formalmente esto es una novedad de la LRJSP, los tribunales ya venían imponiendo esta solución en cuanto a la prescripción de las infracciones ${ }^{56}$. Más allá del formalista argumento de que la prescripción es una institución de naturaleza material y no procedimental ${ }^{57}$, las razones para sostener la retroactividad in bonus de las normas que reduzcan los plazos de prescripción son fútiles: el fundamento material de la retroactividad favorable (la justicia, según vimos) no concurre aquí; el hecho de que sea una institución de carácter material no demuestra que las normas que la regulan sean propiamente punitivas; de hecho, el supuesto no es de ningún modo subsumible en lo que dicen los tratados internacionales que acogen expresamente la retroactividad favorable de normas punitivas. Recuérdese que hablan de la norma que dispone «una pena más leve» ¿Qué tiene que ver «una pena más leve» con un plazo de prescripción más breve? Nada. Por lo demás, el resultado tampoco es razonable pues no lo es que la Administración (o el interesado en que se sancione), confiando en que el plazo de prescripción es, por ejemploi, de dos años y esperando a tener más datos sobre la infracción, se vea sorprendida por una ley que acorte el plazo a un año. Sea como fuere, la LRJSP ha hecho una opción clara. Y, para colmo, la hace sin distinguir entre prescripción de la infracción y de la sanción. Respecto a esto último, los tribunales la han aplicado ya en lo atinente al nuevo régimen de prescripción de la sanción por falta de resolución de los recursos administrativos contra las resoluciones sancionadoras ${ }^{58}$. Ante la clara opción legal, lo único que cabe añadir es que, pese a ello, esta extensión de la retroactividad favorable a la prescripción no tiene rango constitucional y que, por tanto, no sería inconstitucional la ley que consagrara como excepción una solución diferente.

Puede suceder que la norma posterior favorable no solo no estuviera vigente cuando se cometieron los hechos sino que tampoco lo esté en el momento de su definitivo enjuiciamiento porque, a su vez, haya sido modificada por otra: se habla entonces de leyes intermedias; y también respecto a ellas, si son más favorables que la existente al principio y al final, se predica su aplicación ${ }^{59}$.

Se ha discutido si la norma sancionadora posterior favorable comporta la extinción de la responsabilidad sancionadora ${ }^{60}$. Según creo, no cabe una respuesta general: depende de ante cuál de estos tres supuestos

53 Una aplicación extrema puede verse en la STS 457/2021, de 29 de marzo: la nueva ley había disminuido el máximo de las multas por blanqueo de capitales; pero la multa impuesta con anterioridad no superaba ese máximo. Pese a ello la sentencia considera que el nuevo marco legal provoca que la sanción haya devenido excesiva y que el principio de proporcionalidad unido al de retroactividad favorable obliga a recalcular la sanción para disminuirla.

54 López Menudo, El principio de irretroactividad (1982, pp. 196-197). Ejemplo ofrece la STS de 30 de noviembre de 2011 (rec. 5259/2008) ante la caducidad del permiso de conducir por su no renovación en plazo, que suprimió una norma posterior: no procede la aplicación de ésta porque «no nos hallamos ante una norma de naturaleza sancionadora». También STJUE de 13 de julio de 2006 , Maatschap, as. C-45/05, apdo. 58, que no aplica la retroactividad favorable porque entiende que la pérdida del beneficio de que se trataba (prima por sacrificio de bovinos) «no constituye una sanción sino la consecuencia de la inobservancia de admisibilidad para la concesión de la citada prima».

55 A veces no es propiamente que la nueva norma reduzca el plazo de prescripción, sino que disminuye la gravedad de la infracción y ello conduce de rebote a un menor plazo de prescripción. Es lo que sucedía en el caso de la SAN 213/2017, de 5 de mayo, de suerte que, en vez de imponer la sanción más suave que ahora procedía, dejó impune la infracción.

56 Bueno Armijo (2010, pp. 213-214) explica que estas sentencias, sobre todo relativas al plazo de prescripción de las infracciones tributarias que pasó de cinco a cuatro años, se basan en que la prescripción es una institución de Derecho material.

57 Ésa es su concepción dominante en la doctrina penal española. Vid. González Tapia (2003, pp. 42-44).

58 O sea, a lo dispuesto en el art. 30.3.3. LRJSP que da solución al problema que se producía antes de esta ley cuando, mientras no se resolviese expresamente un recurso contra una resolución sancionadora no corría el plazo de prescripción de la infracción ni de la sanción. Lo estudiaron Alarcón Sotomayor (2012, pp. 263 y ss.) y Cano Campos (2012, pp. 70 y ss.). Ahora, gracias al art. 30.3.3. LRJSP, corre el plazo de prescripción de la sanción desde que se produce la desestimación presunta del recurso. Y lo que nos interesa es que las SSTS 1627/2020 y 284/2021 han aplicado retroactivamente esta solución. En realidad, a este respecto lo que hace el TS es asumir la tesis de las sentencias recurridas: «... partiendo de la aplicación retroactiva de la misma (o sea, de la norma del art. 30.3 .3 . $^{\circ}$ LRJSP), ampliamente justificada en la sentencia de instancia, que se comparte por esta Sala y que no es preciso reproducir...». La solución de estas SSTS es lógica, dada la situación absurda que regía antes de la LRJSP. Pero en otros casos la aplicación retroactiva favorable sobre prescripción llevará a resultados mucho menos razonables.

59 Por todos, Morillas Cueva (2018, pp. 243-244), con el argumento habitual de que «el no juzgamiento durante el periodo de vigencia de la ley intermedia no es acahacable al reo sino a la lentitud de la justicia». Asimismo, Gómez Tomillo y Sainz Rubiales (2017, pp. 203-204).

60 En sentido afirmativo Caballero Sánchez (2001, p. 131); en contra, Cano Campos (2018, p. 60). 
de retroactividad se esté; también depende del momento en que la norma favorable entre en vigor (antes o después de que se dicte la resolución sancionadora). En cualquier caso, el que se opte por una solución o por otra no afecta a nada sustancial, ni a las consecuencias invalidante de la resolución que vulnere la obligada retroactividad in bonus ni a las vías para combatirla.

\subsection{La excepción de las normas temporales y de actualización de importes económicos}

Se exceptúa de la obligada retroactividad de las normas punitivas favorables la de aquéllas que sustituyen a las leyes temporales. Se entiende por ley temporal no sólo la dictada para los estados de alarma, excepción y sitio sino toda aquélla que se apruebe para regular solo un periodo de tiempo, ya venga delimitado por referencia a una fecha concreta o por algún acontecimiento (una situación de grave sequía, de polución, etc.) y aunque su carácter efímero no se explicite, sino que se infiera de su contexto ${ }^{61}$. Suelen ser más severas: tanto por tipificar conductas que normalmente no son punibles (y ni siquiera antijurídicas) como por agravar el castigo correspondiente a conductas que también lo tienen previsto en tiempos normales. La excepción de la que hablo entraña que la norma que sustituya a la ley temporal (o sea, la ley que rige de ordinario salvo en ese periodo) no se aplicará retroactivamente, aunque sea, como normalmente será, más benévola. Dicho de otra forma: las conductas realizadas bajo la vigencia de la ley temporal pueden -y hasta deben- ser sancionadas conforme a esa ley aunque cuando sean enjuiciadas ya esté vigente otra más favorable.

Esta excepción la plasma el artículo 2.2 in fine CP. Pero no hay ni vestigios de ella en el artículo 26.2 LRJSP ${ }^{62}$. Y tampoco esta excepción se contempla en el artículo 15.1 del Pacto Internacional de Derechos Civiles y Políticos ni en el 49.1 de la Carta de Derechos Fundamentales de la Unión Europea. Aun así, igual que nadie ha pretendido que esa previsión de nuestros Códigos Penales sea contraria a tales tratados internacionales, incluso se aceptaba antes de que la recogiera expresamente el Código Penal (Lascuraín Sánchez, 2000, pp. 69-71), hay que aceptarla en el Derecho Administrativo sancionador. Es una excepción lógica e imprescindible para evitar resultados injustos y palmariamente irracionales. Así que, por traer un ejemplo actual, la derogación de las normas sancionadoras establecidas para luchar contra la COVID-19 por superación de la pandemia no supondrá (no, al menos, necesariamente) que las conductas infractoras cometidas bajo su vigencia devengan impunes. Sería un despropósito.

También se ha aceptado la excepción de las normas punitivas que aumentan las cuantías que sirven para convertir en delito o en infracción (o para que tengan una calificación más grave) los daños, las defraudaciones o, en general, los ilícitos contra el patrimonio, según se supere un determinado importe. Cuando la elevación de esos umbrales responda a una mera actualización para adecuarse a la depreciación monetaria, aunque aparentemente suponen una norma punitiva más benigna, su no aplicación retroactiva no se considera necesariamente contraria a la regla ${ }^{63}$.

Para justificar que en el caso de las normas temporales y de las que adaptan las cuantías a la depreciación monetaria no debe jugar la retroactividad in bonus se dice que, en tales hipótesis, más que una genuina sucesión de normas punitivas, hay un mero cambio fáctico (Gómez Tomillo y Sanz Rubiales, 2017, pp. 199-

61 Pero no cabe extender el concepto de ley temporal hasta el extremo de incluir a la mayoría de las leyes administrativas por el mero hecho de que están más apegadas a circunstancias coyunturales o variables y acogen una estrategia ante ellas. Seguramente la ley que regule el sector eléctrico o el impuesto sobre la renta tendrán menos vigencia que las normas de, por ejemplo, Derecho sucesorio, y hasta cabe reconocer que el legislador parte ya de que habrá que ir modificándolas según nuevas circunstancias. Pero eso no las convierte de ningún modo en leyes temporales como parece asumir López Menudo (1982, pp. 205 a 208).

62 Peor todavía: en la Ley Orgánica 4/1981 de los Estados de Alarma, Excepción y Sitio tampoco está recogida esta salvedad sino otra mucho más reducida: su art. 1.3 solo salva a las «sanciones firmes», o sea, las sanciones que no solo se impusieron cuando regía alguno de esos estados extraordinarios, sino que además alcanzaron firmeza durante ese periodo. De modo que parece que, tras levantarse estos estados extraordinarios, no cabría imponer nuevas sanciones por hechos producidos durante su vigencia y en aplicación de sus específicas normas punitivas. Por supuesto que las sanciones devenidas firmes mientras duran esos estados extraordinarios deben mantener su eficacia; pero es que, además, lo razonable es que, terminados esos estados, puedan ejecutarse las sanciones impuestas, aunque aún no hayan devenido firmes y puedan sancionarse las infracciones cometidas mientras estuvieron declarados. De lo contrario la mayoría de las conductas quedarían impunes con patentemente injusticia y arruinando la efectividad de ese derecho excepcional. Cano Campos (2021, pp. 819-820), acudiendo al origen de este desgraciado precepto, trata de salvar sus más disparatadas consecuencias.

63 Vid. Rodríguez Mourullo (1997, p. 135); Lascuraín Sánchez (2000, pp. 99-100); y Gómez Tomillo y Sanz Rubiales (2017, p. 200). Cosa distinta es que, aun así, se pueda optar por esa aplicación retroactiva favorable, como hizo el Acuerdo de la Sala de lo Penal del TS de 25 de octubre de 2005. Vid. Muñoz Conde y García Arán (2019, p. 133). Solo afirmo que no hacerlo no comporta vulneración de la regla analizada. 
200), (Cano Campos, 2018, p. 59). Y, yendo más al fondo, se explica que en estos casos el legislador no ha variado un ápice su juicio sobre la conducta atendiendo al momento y circunstancias en que se realizó. No hay un cambio valorativo, se dice; no ha perdido vigencia la reprobación que al ordenamiento le merece la acción en el contexto en que se realizó (Lascuraín Sánchez, 2000, pp. 42-50). Todo esto es correcto. Tan correcto que, en realidad, puede y debe justificar otras excepciones, como luego razonaré.

\subsection{Retroactividad in bonus de reglamentos ejecutivos y de criterios interpretativos}

Los reglamentos sancionadores que pueden dictarse conforme al artículo 27.3 LRJSP han de aplicarse retroactivamente en cuanto sean favorables ${ }^{64}$. Y lo mismo puede decirse de los criterios interpretativos, ya sean los incorporados a una norma, los jurisprudenciales o los expresados por la Administración ${ }^{65}$. A este respecto no se plantean dudas ni problemas especiales.

\section{5. ¿Retroactividad in bonus de las normas no sancionadoras en cuanto se integran con las sancionadoras? La respuesta dominante y la conveniente matización}

En Derecho Penal se suele aceptar que las normas no penales, en cuanto están llamadas a integrarse con las penales en blanco, deben de aplicarse retroactivamente si favorecen al reo ${ }^{66}$. Y ésa es también la solución que acoge la jurisprudencia para las normas no sancionadoras que se integran con las sancionadoras administrativas ${ }^{67}$. Lo expresó claramente la STS de 12 de febrero de $1988^{68}$. Tras recordar que en el Derecho Administrativo sancionador rige la retroactividad in melius, dice:

"Ocurre que en ocasiones la norma sancionadora no describe exhaustivamente la conducta que integra la infracción sino que se remite a otros preceptos a los que corresponde la función de rellenar aquel vacío completando así el tipo (...) La cuestión suscitada es la de si el principio de la retroactividad de la ley más favorable ha de jugar también cuando lo que se modifica no es la norma sancionadora, en sí misma, sino la que aporta el complemento que viene a rellenar el tipo en blanco por aquella dibujado. La respuesta (...) ha de ser afirmativa: el complemento que proporciona la norma no sancionadora es siempre parte integrante del tipo. Que éste se formule de una sola vez, en la regla sancionadora, o en dos momentos y normas distintas, resulta inoperante. La infracción se integra por el tipo completo (...) Así las cosas, a los efectos de la retroactividad de la ley más favorable, una vez que el tipo existe, resulta intrascendente que la alteración o eliminación tenga lugar por modificación de la norma sancionadora en blanco o por modificación de la regla complementaria que viene a dar el último contenido al tipo. El fundamento de la retroactividad de la norma sancionadora más favorable, se concrete en razones humanitarias o de estricta justicia, opera siempre que una modificación normativa afecte a la norma en blanco o a la complementaria (lo que) evidencia que determinada conducta ha dejado de ser socialmente reprochable» ${ }^{69}$.

${ }^{64}$ Y lo mismo hay que afirmar, incluso con más razón, de las normas sancionadoras que, más allá de los límites del art. 27.3 LRJSP, puedan contener ordenanzas o reglamentos colegiales.

65 Sobre un criterio interpretativo expresado formalmente por la Administración atinente a la graduación de la sanción, la STSJ de Madrid 194/2016, de 9 de marzo (rec. 487/2015) dice que «al ser (...) favorable al sancionado, debería haberse aplicado con carácter retroactivo». Por ello rebaja la multa de 30.050 a $3.006 €$.

66 Rodríguez Mourullo (1997, p. 136): «en la medida en que integran una ley penal se convierten en normas de esta naturaleza». La jurisprudencia penal sigue desde hace tiempo esta tesis. Vid. Lascuraín Sánchez (2000, pp. 80 a 83)

67 En la doctrina administrativista es rotundamente favorable a esta aplicación retroactiva (Gallardo Castillo, 2008, pp. 146-147).

68 No aparece el número del recurso. Para la identificación de esta importante sentencia diré que está publicada dos veces con ECLI diferente: ES:TS:1988: 1144 y 15588. Y en el repertorio Aranzadi aparece con el n. ${ }^{\circ} 1378$.

69 La misma idea ha venido aplicándose ampliamente por los tribunales contencioso-administrativos. Vid. Bueno Armijo (2010, pp. 210-213). La expresa con claridad la STS, Sala Militar, de 17 de marzo de 2016 (rec. 139/2015) que, con cita de otras anteriores de la misma Sala, afirma que «en el ámbito penal no existe la menor duda de que en el supuesto (...) de las leyes penales en blanco (en blanco, en sentido amplio o con elementos normativos) que se remiten expresa o tácitamente a otras normas jurídicas exprapenales (...) cualquier norma extrapenal que limite el alcance del supuesto de hecho de la ley remitente dará lugar a una nueva ley penal que deberá aplicarse retroactivamente». Y lo aplica al ámbito disciplinario de forma que, «proyectada la nueva norma al tipo disciplinario en cuestión, limita su alcance, siendo por tanto más favorable para el recurrente, de ahí su directa aplicación...». Asimismo, es la postura dominante en la doctrina administrativista. Por todos, López Menudo (2018, p. 92): tanto «la irretroacción en lo desfavorable y la 
No se trata siempre de integración con reglamentos sino a veces con otras leyes $u$ otros elementos normativos; incluso convenios colectivos ${ }^{70}$. Y, en realidad, similar idea se aplica más allá de las genuinas normas en blanco cuando hay un nuevo contexto jurídico que comporta que ya no hay tipicidad o, más frecuentemente, que, aunque haya tipicidad, ya no hay antijuridicidad. Son supuestos heterogéneos difícilmente reconducibles a unidad. Ejemplifiquémoslos con algunas sentencias del TS.

- STS de 22 de febrero de 2005 (recurso 2278/2002). Se sancionó por realizar una actuación en unos terrenos que en aquél momento estaban en un parque protegido. En virtud de una modificación legislativa, esos terrenos quedaron fuera de los límites de ese parque. Y la sentencia anuló la sanción con este razonamiento:

«Tal modificación legislativa (...) ha supuesto que la finca en la que se llevaron a cabo los hechos sancionados ya no se encuentran dentro de los límites del Parque Regional, habiendo desaparecido las limitaciones y prohibiciones contenidas en la misma, y, en consecuencia, la presunta infracción (...) Desde una perspectiva de constitucionalidad, la retroactividad de las disposiciones sancionadoras más favorables, deducida a contrario sensu de artículo 9.3 de la Constitución, obliga a la estimación del recurso en supuestos como el presente en que el acto impugnado tiene un exclusivo carácter sancionador. Y, desde la perspectiva de legalidad ordinaria ha de llegarse a idéntica conclusión, de conformidad con el artículo 128.2 de la Ley 30/1992 (hoy art. 26.2 LRJSP), en el cual se establece que "las disposiciones sancionadoras producirán efecto retroactivo en cuanto favorezcan al infractor"».

- STS de 15 de julio de 1999 (rec. 132/1993): se impuso sanción por infracción de contrabando cometida en 1982 por la importación de productos adquiridos en Francia. Tras la incorporación de España a la Comunidad Europea la importación de productos franceses dejó de estar sometida a restricciones. Por tanto, explica el TS, ahora la conducta no sería infracción y, dice, procede «declarar extinguida la responsabilidad ${ }^{71}$.

- STS de 6 noviembre 1998 (rec. 535/1993): se sancionó por comercializar en 1979 con productos que eran objeto del monopolio de petróleos. Como en 1992 se suprimió tal monopolio, al resolver el TS la conducta ya no sería infracción. Por eso declara «extinguida la responsabilidad».

Otros tribunales han aplicado lo mismo, por ejemplo, ante las reformas del tiempo máximo de publicidad de los canales televisivos ${ }^{72}$ o cuando se ha sustituido la exigencia de autorización administrativa por la de mera comunicación a la Administración ${ }^{73}$.

Estos ejemplos son de por sí sugerentes para dudar de la justicia de los resultados de esta retroactividad in bonus (Nieto García, 2012, p. 206). ¿Es justo que quede sin sanción quien vulneró las normas de un parque protegido porque después perdió la protección? ¿Lo es si perdió la protección precisamente porque los particulares, con su indisciplina, provocaron la degradación de sus valores ambientales? ¿Es justo que quien importaba ilegalmente productos franceses, cuando sus competidores pagaban aranceles y cuando los productos españoles no podían exportarse libremente a Francia, quede sin sanción porque después todo eso cambio? ¿Tiene algo que ver con la justicia que quede sin sanción quien vulneraba el monopolio de pe-

retroacción en lo beneficioso juegan a plenitud cuando lo que se modifica no es la norma sancionadora en sí misma sino la que aporta el complemento que viene a rellenar el tipo en blanco por aquella dibujado».

70 Sirve de ejemplo la STSJ de Cantabria de 27 de abril de 2001 (rec. 441/2000). Se sancionó de acuerdo con la norma del Estatuto de los Trabajadores que tipifica como infracción «la transgresión de las normas y límites legales o paccionados en materia de jornada, trabajo nocturno, horas extraordinarias...». Explica el Tribunal que se trata de «un precepto sancionador en blanco (que) hace necesario acudir a otra norma, en este caso, al convenio colectivo». Como después de cometerse la infracción se pactó un nuevo convenio colectivo que permitía el trabajo los sábados por la tarde, que es lo que se imputaba a la sancionada, la sentencia, en aplicación de la retroactividad in bonus, anula la multa impuesta.

71 Algo parecido puede verse en las sentencias relativas a la expulsión de rumanos y búlgaros que, tras la incorporación de sus países a la Unión Europea, fueron anuladas invocando la retroactividad in bonus. Entre otras, SSTS de 12 y 13 de febrero de 2008 (rec. 2525 y $2110 / 2004)$.

72 SSAN de 16 y 19 de diciembre de 2013 (rec. 1020 y 824/2013): la ley seguía tipificando la superación de los límites temporales de publicidad; pero las normas que fijaban esos límites habían procedido a una reordenación general de la publicidad televisiva.

73 Por ejemplo, STSJ de Canarias (Sala de Las Palmas) 106/2013, de 4 de noviembre: de acuerdo con la ley turística que tipificaba como infracción la explotación de hoteles sin autorización, se impuso una multa. Con posterioridad se suprimió la necesidad de autorización y se sustituyó por comunicación previa. La sentencia dice que está ante «un precepto en blanco que es preciso llenar con preceptos que establezcan los supuestos en los que legal o reglamentariamente» se imponga la necesidad de autorización. Como ahora rige «el principio de libertad de establecimiento sin necesidad de autorización», afirma que la conducta «ha dejado de ser típicamente antijurídica» por lo que anula la sanción. 
REALA. Nueva Época - N. 16, octubre 2021 - ISSN: 1989-8975 - DOI: https://doi.org/10.24965/reala.i16.10961 - [Págs. 6-32]

Sucesión de normas administrativas sancionadoras: irretroactividad y excepciones

Manuel Rebollo Puig

tróleos porque luego se liberalizó? ¿O quién infringió los límites temporales de publicidad porque después se establecieron otros no menores sino distintos que, claro está, tampoco había observado? ¿Debe quedar sin sanción quien actuaba clandestinamente porque después se sustituyó la autorización por mera comunicación que tampoco había realizado? Y más allá de estos ejemplos de las sentencias, piénsese en los cambios en las infracciones de tráfico ¿Es justa la impunidad de quien circula en dirección prohibida porque luego se produce una reordenación y para la misma calle se establece la dirección contraria? ¿La de quién supera el límite de velocidad porque después, acaso por mejorar las condiciones de la vía, se suprime ese límite? (Cano Campos, 2014, pp. 145-147).Y las normas tributarias ofrecen ejemplos elocuentes ¿Es justo que quede impune quien no pagó determinado impuesto porque después se suprime y se sustituye por otros que, naturalmente, tampoco pagó? (Lascuraín Sánchez, 2000, pp. 103-116). En estos casos el infractor ¿será un precursor, un avanzado con una idea del orden social a la que el tiempo ha dado la razón o un descarado transgresor de la legalidad con suerte? Negar la justicia de los resultados a que conduce esta indiscriminada aplicación de la retroactividad in bonus no es baladí pues recuérdese que su fundamento es la justicia material. ¿Debe aplicarse la regla positiva del artículo 26.2 LRJSP desconectada de su fundamento e incluso cuando conduce a resultados ridículos y hasta sangrantes?

En algunas sentencias se atisba una cierta reacción, un intento de contener esta aplicación desbocada de la retroactividad in melius. Lo entreveo en la STS de 18 de marzo de 2003 (recurso 5721/1998). La infracción consistía en «la cesión de trabajadores en los términos prohibidos por la legislación vigente» y lo que había cambiado era esa legislación que pasó de «la prohibición en términos absolutos» a su admisión con determinados requisitos y necesidad de autorización administrativa. La recurrente fue sancionada por realizar la cesión cuando estaba totalmente prohibida y pretendía que se anulara la sanción porque después esa prohibición había sido derogada. La sentencia acude a la doctrina de las normas temporales para rechazar la retroactividad in melius. Parece obvio que la prohibición absoluta de cesión de trabajadores no era una norma temporal y que su invocación fue un subterfugio para rechazar una solución que la sentencia intuía injusta. Además, hay en esta misma sentencia otros argumentos más sólidos. Apunta que lo que sucede es que la sucesión de normas «no supone necesariamente un cambio de criterio sobre la idoneidad de las penas señaladas por dichas leyes para quienes las infringieron durante su vigencia»; y que en el caso «se infiere que el legislador no ha cambiado de criterio sobre la adecuación de las sanciones impuestas». Para los supuestos en que una actividad deja de ser antijurídica y pasa a ser lícita pero con una serie de requisitos, también esboza este otro argumento: «El hecho de que dichos requisitos no pudieran cumplirse cuando se llevó a cabo la cesión (...) lleva a la conclusión de que el régimen sancionador aplicable al caso es en su integridad el previsto en la legislación derogada».

Sobre todo, es reveladora la STSJ de Galicia 215/2014, de 6 de marzo. Un sujeto fue sancionado en virtud del precepto que tipifica como infracción muy grave realizar en suelo rústico una edificación prohibida. Después se modificó el plan urbanístico: el terreno pasó a ser suelo de núcleo rural en el que sí era posible construir. Según el sancionado, ya no se estaba ante la infracción muy grave sino ante la leve de construir sin licencia un edificio legalizable. En la primera instancia el Juzgado anuló la sanción por entender que la conducta había quedado destipificada y por la retroactividad in bonus. Pero la STSJ reseñada, como ya había hecho el mismo tribunal en otras, dice que se trata de «una norma en blanco porque se remite a otras, que son las que determinan qué actividades están prohibidas en suelo rústico»; que sólo hay una «posterior aprobación de instrumento de planeamiento que desplegará sus efectos hacia el futuro»; y que no se produce «un supuesto de retroactividad de norma sancionadora más favorable, ya que dicha norma sancionadora sigue siendo la misma». Y explica:

«No cabe hablar de retroactividad de una norma más favorable porque el precepto aplicado por la Administración sigue siendo el mismo, por lo que también sigue siendo una infracción muy grave realizar en suelo rústico una obra prohibida por la ley; y para determinar la clasificación del suelo (...) hay que estar al momento en que se llevó a cabo la obra, en el cual se trataba de un suelo rústico en el que no se podía edificar una vivienda como la que construyó el actor (...) Cuando (la ley) califica como infracción leve la ejecución de una obra realizada sin licencia en el caso de ser legalizable por ser conforme con el ordenamiento urbanístico, se está refiriendo al ordenamiento en vigor cuando se ejecuta la obra, ya que esa calificación como leve deriva de que no existió un desconocimiento de la legalidad urbanística material, pues no se construyó algo prohibido, sino de la procedimental al no haber sido solicitada la oportuna licencia». 
En definitiva, en caso de norma sancionadora en blanco que ha de integrarse con los planes de urbanismo, la modificación de estos no arrastra su aplicación retroactiva, aunque permitan lo hasta entonces prohibido. El asunto llegó al TS, no por vía de recurso, sino porque el sancionado planteó nada más y nada menos que proceso por error judicial a efectos de la responsabilidad patrimonial del Estado. Y la STS 1821/2016, de 18 de julio, se limitó a decir que las conclusiones del tribunal gallego «no pueden reputarse ilógicas, irrazonables o absurdas, ni tampoco fruto de la desatención, la desidia o falta de interés jurídico, sino que, por el contrario, constituyen claramente el resultado de un proceso razonado y acorde con las reglas del criterio humano, sin que ello signifique que sean compartidas por esta Sala» ${ }^{74}$. Ni compartidas ni rechazadas. Pero, según creo, aquella sentencia del TSJ gallego no sólo no era ilógica sino impecable: la retroactividad favorable no puede extenderse a tales casos; lo contrario produce disfunciones graves, especialmente agudas cuando los planes se modifican precisamente para dar solución a las situaciones creadas por la indisciplina: que con esas modificaciones de planes se eviten demoliciones problemáticas tiene un pase, pero que para colmo los responsables también queden sin castigo es un infame desatino.

En algunas otras sentencias, aunque no se refieran a normas sancionadoras en blanco sino a cambios legislativos que alteran aspectos de la antijuridicidad y aunque no expliquen sus razones, también se esquiva la retroactividad in bonus cuando perciben que conduce a resultados inicuos. Son representativas las SSTS de 7 de diciembre de 2015 y 22 de febrero de 2016 (rec. 1758 y 1419/2013): ante una infracción contra la competencia (con ocasión de los contratos de adquisición de derechos audiovisuales de la Liga y la Copa del Rey) que, días después de la resolución sancionadora, resultaba lícita conforme a la Ley General de Comunicación Audiovisual (a su art. 21 y a su transitoria 12. ${ }^{a}$ ), el TS simplemente dice que «el nuevo régimen jurídico aplicable a los contratos de adquisición de los derechos audiovisuales de los clubs de fútbol, no puede condicionar la conformidad a derecho o nulidad de la resolución administrativa sancionadora, de fecha anterior a la entrada en vigor de la nueva norma». Según creo, se estaba ante uno de los casos comprendidos en el artículo 4.1 de la Ley de Defensa de la Competencia: «...las prohibiciones del presente capítulo no se aplicarán a las conductas que resulten de la aplicación de una ley». La Ley de Comunicación Audiovisual era una de esas leyes: hacía que conductas típicas según la Ley de Defensa de la Competencia no resultaran sancionables porque no son antijurídicas. Por tanto, la aplicación tajante y amplia de la retroactividad sancionadora favorable conducía a la anulación de la sanción. Lo que hacen estas SSTS con la afirmación apodíctica reproducida es simplemente negar tal aplicación retroactiva de una ley que excluía la antijuridicidad.

También ocasionalmente se vislumbra esta reacción frente a la aplicación amplia de la retroactividad sancionadora favorable en el TJUE. Buena muestra es su sentencia de 11 de marzo de 2008, Jager, as., C-420/06, apdos. 67 a 85, ante el cambio en el régimen de las ayudas agrarias. Frente a la pretensión de la aplicación retroactiva del régimen sancionador posterior, el tribunal explica que se trata de un «contexto normativo esencialmente distinto», de un nuevo "sistema global», y que por ello el nuevo régimen sancionador «no refleja un cambio de apreciación del legislador comunitario en cuanto al carácter adecuado de las sanciones» previstas en el anterior de modo que no cabe aplicar retroactivamente las normas punitivas posteriores «so pena de desnaturalizar el régimen (...) tal y como ha sido concebido por el legislador comunitario en el marco de dicha reforma».

Tratando de dar una explicación general, lo que sucede en muchos de estos casos en que no cambia la norma sancionadora sino otras con las que se integra o le dan su contexto jurídico es que -igual que ocurre con la derogación de leyes temporales o con las de adaptación a la depreciación del dinero- la reforma no entraña un cambio en la valoración que la conducta merece al ordenamiento. Ese cambio de valoración acaso se exprese con la destipificación o con la previsión de sanción menor, pero no con otras mutaciones del ordenamiento. Con esas otras reformas puede y suele haber solo un cambio de estrategia o mera adecuación a otra coyuntura. Incluso aunque haya un cambio radical en todo un sistema (en el fiscal, en el urbanístico de un territorio, en el de un sector económico...) y se entienda que supone una mejora, no se desdeña lo establecido antes ni se altera el juicio peyorativo que el ordenamiento hace de quien lo transgredió. Por eso sancionar las conductas contrarias a la norma derogada conserva su justicia y racionalidad. Igual que, permítaseme el símil, si se pasa del fútbol al baloncesto nadie en su sano juicio dejaría sin sanción a quien jugó al fútbol con la mano.

74 Es sorprendente que el Ministerio Fiscal solicitó la estimación de la demanda -o sea, que consideraba que la sentencia había incurrido en manifiesto error judicial- por entender que es «obligada la aplicación retroactiva del Plan de 2012 como norma más favorable». 
Lo razonado conduce a concluir que debería permitirse al legislador que modulara o hasta excluyera la retroactividad in bonus. Así sería él quien declararía si con la reforma que introduce hay o no un cambio valorativo respecto a las conductas anteriores. Nadie mejor que quien introduce esa reforma para hacerlo. Pero esto, en realidad, significa que la postura correcta es la del sector doctrinal que propugna que la retroactividad in bonus no tiene rango supralegal y que, por tanto, el propio legislador la puede moldear y excepcionar. $Y$ aunque parezca la mejor tesis, choca, como nos consta, con los tratados internacionales que la han consagrado y con la jurisprudencia del TC que la ha constitucionalizado.

Ante ello, lo que defiendo es que, al menos, se constriña la obligada retroactividad favorable dentro de lo que inexorablemente imponen esas normas supralegales y el artículo 26.2 LRJSP. Es decir, que sólo juegue respecto a las normas estrictamente sancionadoras y que, por tanto, queden al margen de la imperativa retroactividad in bonus las otras con las que se integran o que ofrecen el contexto de antijuridicidad. Para entender bien esta propuesta, una precisión es pertinente: con ella no se pretende que se sancione la conducta previa por el mero hecho de que constituya desobediencia a las normas a la sazón vigentes ni, por tanto, castigarlas puramente por su mera antijuridicidad formal; se trata más bien de permitir sancionarla porque, pese al cambio normativo, se sigue reconociendo en aquella conducta su lesividad para el bien jurídico protegido (el medio ambiente, la seguridad del tráfico vial, la salud pública, la ordenación urbana, etc.), esto es, su antijuridicidad material.

Esta interpretación que patrocino no es incompatible ni con los textos internacionales ni con lo que ha consagrado el TC español. Es perfectamente conciliable con ello y hasta con el artículo 26.2 LRJSP. Simplemente circunscribe su ámbito a lo que realmente dicen y a lo que concuerda con el fundamento material de la retroactividad in melius. Incluso cabe afirmar que, aunque formalmente no ha sido proclamada por la jurisprudencia ordinaria y hasta contradice algunas de sus declaraciones generales, realmente explica y da sustento teórico a lo que han hecho algunas sentencias que, como se ha visto, sin aparente fundamento o con fundamentos inconsistentes, huyen de la aplicación ciega y rígida de la retroactividad favorable de las normas que ofrecen el contexto de antijuridicidad de las estrictamente sancionadoras.

\subsection{Retroactividad de las leyes que dan cobertura a reglamentos favorables}

El TS ha admitido la retroactividad de las leyes que a posteriori dan sustento a reglamentos sancionadores favorables que nacieron sin ella ${ }^{75}$. Pero, en concordancia con lo dicho en relación con los reglamentos desfavorables, cabe sostener que, al margen de la cuestión de la retroactividad in melius, si el reglamento nació nulo, la ley posterior no puede sanarlo.

\subsection{Sobre las normas procedimentales y las relativas a la ejecución de las sanciones}

Por las mismas razones que vimos en relación con la retroactividad in peius, tampoco las normas procedimentales posteriores a los hechos enjuiciados quedan sometidas a la obligatoria retroactividad in melius de que aquí hablamos ${ }^{76}$. Aunque frecuentemente resultarán de aplicación a conductas realizadas antes de su vigencia, eso se produce en virtud de reglas por completo diferentes. Y lo mismo hay que decir de las atinentes a la ejecución de las resoluciones sancionadoras ${ }^{77}$.

75 Por ejemplo, las SSTS de 18 de julio y 18 y 25 de octubre de 2011 (rec. 224, 228 y 281/2010) admitieron la aplicación de una ordenanza barcelonesa que sin previa base legal establecía la sustitución de las multas por la realización de trabajos en favor de la comunidad o la asistencia a sesiones informativas al entender que era favorable y que le dio cobertura poco después el art. 30.3 de la Ley 1/2006 de Régimen Especial de Barcelona.

76 Así, la STS de 18 de noviembre de 2008, rec. 1744/2006. En el caso, una reforma había reducido el plazo de duración del procedimiento y, por ende, anticipado el de caducidad: «no puede ser considerada como norma sancionadora susceptible de aplicarse con efecto retroactivo. Se trata de una norma de procedimiento que tiene virtualidad a partir del momento de su entrada en vigor, con proyección sólo de futuro, al no afectar para nada a la calificación de la infracción o de la sanción que le corresponde, campos en los que opera el principio de retroactividad de la ley favorable, sin que pueda extenderse más allá de este ámbito el indicado principio conforme a la doctrina del TC (STC de 23 de octubre de 2006 y las que en ella se citan)». No obstante, defiende esa retroactividad Gallardo Castillo (2008, pp. 147-148).

77 Una serie de SSTS de la que es muestra la de 4 de febrero de 2002 (recurso 7382/1996) aplican la nueva norma posterior a la infracción que establecía la suspensión automática de las sanciones tributarias frente a la anterior que exigía la prestación de garantía. Pero, sin negar su acierto, sostengo que la solución no se basaba en la regla constitucional de retroactividad de las leyes punitivas favorables, sino que tenía otros fundamentos. 


\subsection{Intrascendencia del momento en que se cometiera la infracción}

A diferencia de lo que se plantea para la prohibición de la retroactividad in peius de las normas punitivas, aquí, a efectos de la obligada retroactividad in melius, es superfluo determinar con exactitud el momento de comisión de la infracción: se aplicará la norma posterior más benigna, aunque la infracción se haya cometido íntegramente bajo la vigencia de la más severa y aunque aquélla favorable se aprobara mucho después (González Tapia, 2002, pp. 105 y 216) ${ }^{78}$.

\subsection{Procede esta aplicación retroactiva mientras no se haya ejecutado la sanción y mientras, incluso ejecutada, no sea firme}

El artículo 26.2 LRJSP dice que la aplicación favorable procederá «incluso respecto a las sanciones pendientes de cumplimiento al entrar en vigor la nueva disposición ${ }^{79}$.

Queda claro, por lo pronto, que sólo cierra la aplicación de la norma retroactiva favorable cuando la sanción que correspondía en aplicación de la anterior ley más gravosa esté cumplida. Para ser más exactos, completamente cumplida ${ }^{80}$. No distingue el artículo 26.2 LRJSP según la resolución sancionadora sea o no firme cuando entra en vigor la nueva norma favorable. No es un olvido sino una decisión consciente y acertada. Con toda lógica, la firmeza de la resolución no impide que se despliegue esta retroactividad favorable si la sanción no se ha cumplido por completo (Gómez Tomillo y Sanz Rubiales, 2017, p. 188). Para las normas penales, lo proclama el artículo $2.2 \mathrm{CP}$ español: «...tendrán efecto retroactivo aquellas leyes penales que favorezcan al reo, aunque al entrar en vigor hubiera recaído sentencia firme...». No hay ninguna razón para que la solución sea distinta ante las normas sancionadoras administrativas ${ }^{81}$. O sea, la firmeza de las resoluciones sancionadoras (por no haberse recurrido o por haber sido confirmada en sentencia, a su vez firme) no impide la aplicación retroactiva de la norma posterior más benévola si la sanción no estuviera ejecutada en nada o no lo estuviera por completo ${ }^{82}$.

78 Es lo que concluye la STS de 16 de diciembre de 2015 (rec. 1973/2014): se planteaba la aplicación de la Ley de Defensa de la Competencia 16/1989 o la que la sustituyó 15/2007 ante una infracción permanente que se había prolongado desde el año 2000 al 2008. Pero finalmente dice que, en tanto la última sea más beneficiosa, debe aplicarse «incluso en aquellos casos en que las conductas hayan finalizado con anterioridad a la entrada en vigor de la Ley 15/2007».

79 Es una de las novedades del art. 26.2 LRJSP respecto al precedente art. 128.2 Ley 30/1992. Seguramente en la misma línea está otra de sus novedades: en vez de hablar solo de normas que favorezcan «al presunto infractor», como hacía aquel art. 128.2, se refiere a normas que favorezcan «al presunto infractor o al infractor»; con ello pretende destacar que esta retroactividad beneficia también a quien ya ha sido sancionado (el infractor) y no únicamente a aquél simplemente acusado (presunto infractor). De hecho, la referencia única en la Ley 30/1992 al «presunto infractor» sirvió para justificar una gran limitación en la aplicación de la retroactividad in melius. Vid. M. J. Gallardo Castillo (2008, p. 145).

80 El art. 2.2 CP español es más explícito («... el sujeto estuviese cumpliendo la condena»). Pero la misma solución ha de aplicarse a las sanciones administrativas que se prolongan en el tiempo. Así, si se trata de una sanción temporal (por ejemplo, inhabilitación o cierre de establecimiento por cinco años) que se haya cumplido todo el tiempo; si, por ejemplo, se llevan cumplidos cuatro años de inhabilitación o de cierre, la retroactividad in bonus desplegará sus efectos; violaría la obligada retroactividad favorable que se hiciese cumplir el resto de la sanción todavía no ejecutada (el año restante, en nuestro ejemplo) cuando entra en vigor la ley que ya no prevé esa sanción. Y si se trata de una sanción de efectos permanentes, por ejemplo, la separación y baja definitiva como funcionario, la retroactividad in melius podría aplicarse en todo momento. Es lo que subyace, aunque no lo explicite, en la STS de 13 de marzo de 1992 (rec. 3173/1990). En contra STS de 17 de diciembre de 2007 (rec. 183/2004) ante una sanción de separación de servicio con el débil argumento de que ese género de sanciones, una vez «cumplimentados los trámites correspondientes (...) han de entenderse definitivamente ejecutadas y, por lo tanto, no son susceptibles de rectificación por aplicación retroactiva de la ley penal más benigna». Más bien se puede mantener que si la sanción sigue produciendo efectos aflictivos, deben cesar. Es sugerente la STJUE de 15 de enero de 2019 , as. C-258/17, sobre un policía austriaco castigado por actos homosexuales en 1975. Por esa sanción, el policía sufría una disminución en su pensión del $25 \%$. La sanción devino contraria a la Directiva 2000/78. Y aunque la sanción era firme desde hacía muchos años la STJUE de 2019 eliminó la reducción del $25 \%$ de la pensión. No se basó, sin embargo, en la retroactividad in bonus. Pero en el fondo late esa idea de la supresión de los efectos aflictivos de la sanción que se siguen produciendo.

81 Como se ve, hasta la fuerza de cosa juzgada material de las sentencias firmes se desvanece ante la retroactividad in bonus. Y así debe ser por las razones de justicia que, según vimos, laten en esta retroactividad favorable. Aunque, a fuer de exactos, no se afecta a la cosa juzgada material puesto que no se atenta a lo que decidió en aplicación de una ley sino que se aplica otra. En contra, López Menudo (1982, pp. 199-200), bien es cierto que lo hacía en un contexto normativo distinto del actual.

82 Hay que reconocer, empero, que la Ley General Tributaria no tiene empacho en establecer lo contrario. Dice su art. 10.2.2. que «las normas que regulen el régimen de infracciones y sanciones tributarias (...) tendrán efectos retroactivos respecto de los actos que no sean firmes cuando su aplicación resulte más favorable para el interesado». Concuerda con el art. $178.2 .^{\circ} \mathrm{LGT}$ que, ya referido específicamente a los «principios de la potestad sancionadora», dice: «El principio de irretroactividad se aplicará con carácter general, teniendo en consideración lo dispuesto en el apartado 2 del artículo 10 de esta ley». Es decir, que restringe la retroactividad in bonus a las resoluciones no firmes. Hasta las sentencias penales firmes, como acabamos de ver, se pliegan a la retroactividad favorable. Pero, 
Pero aún hay más, aunque no lo diga el artículo 26.2 LRJSP: en el caso de que la resolución sancionadora esté completamente cumplida, si no ha alcanzado firmeza cuando entra en vigor la norma más favorable, debe desplegar sus efectos la retroactividad in bonus ${ }^{83}$. Piénsese, por ejemplo, que el sancionado, aunque interpuso recurso contra la sanción, prefirió no pedir la suspensión (o la pidió y no la obtuvo) y la cumplió; o incluso optó por pagar durante el procedimiento sancionador para obtener un descuento (art. 85.2 LPAC) sin perjuicio de interponer recurso contencioso-administrativo ${ }^{84}$. En estos casos, aunque la sanción esté cumplida, al no ser firme la resolución que la impuso y estar pendiente de recursos, la nueva norma favorable será aplicable (Bueno Armijo, 2010, pp. 215 y ss.) Así se desprende de la jurisprudencia que expondré en el siguiente epígrafe ${ }^{85}$.

Todo esto lo ratifica la STS 457/2021, de 29 de marzo: «... los cambios legislativos que beneficien al infractor se aplican (...) a las sanciones ya impuestas que no sean firmes, e incluso a éstas cuando no estén totalmente ejecutadas». En conclusión, la retroactividad in bonus únicamente quedará cerrada si la nueva norma favorable entra en vigor cuando la resolución sancionadora sea firme y, además, esté completamente cumplida ${ }^{86}$ : si falta alguna de esas dos condiciones la norma favorable posterior sí será aplicable.

Lo expuesto se asemeja a lo que se produce cuando una norma sancionadora es anulada: también entonces, desde que se declara esa nulidad, no solo no cabrá aplicar esa norma en el futuro (ni siquiera a los hechos que se produjeron durante su aparente vigencia) sino que perderán sus efectos las sanciones impuestas conforme a ella incluso aunque hayan devenido firmes siempre que no estén completamente ejecutadas ${ }^{87}$. Pero, aunque de consecuencias parecidas, son fenómenos muy distintos y con diferente fundamento ${ }^{88}$. Por eso, además, el régimen de la nulidad de normas punitivas y el de la retroactividad in bonus son diferentes (por ejemplo, en cuanto a los cauces para hacer valer una y otra).

\subsection{Consecuencias de la violación de la regla y cauces para eliminarla}

También a este respecto hay que diferenciar según se viole la regla como mandato a la ley sancionadora y como mandato al órgano administrativo encargado de aplicarla.

La norma que niegue la aplicación retroactiva in bonus en materia sancionadora será inconstitucional por contraria al artículo 9.3 CE (aunque no al art. 25.1 CE). Frente a ella cabrá recurso (y cuestión) de inconstitucionalidad o contencioso-administrativo según tenga rango de ley o de reglamento.

En cuanto a la resolución administrativa que no aplique la norma sancionadora favorable hay que distinguir diferentes supuestos según esa norma haya entrado en vigor antes o después de la resolución, de su firmeza o de su ejecución.

al parecer, la LGT pretende que las meras resoluciones de la Administración tributaria sean más inamovibles que las sentencias penales. Dejemos al margen esta extravagancia de la LGT que patentiza una patología más amplia del Derecho español.

83 Cano Campos (2018, p. 59): «... siguiendo a la jurisprudencia (...) la retroactividad in bonus alcanza tanto a las sanciones cumplidas (voluntariamente) o ejecutadas (forzosamente) pero que todavía no son firmes (...) como a las que son firmes, pero todavía no se han cumplido o ejecutado».

84 Que este recurso es posible lo deja claro la STS 232/2021, de 18 de febrero.

85 Además, la solución contraria produciría un resultado injusto que trataría mejor al rebelde contumaz que no cumple (quizá ni siquiera recurrió y no cumple porque «no le da la gana») que a quien cumplió y recurrió; aquél se beneficiaría de la retroactividad in bonus y éste no: injusto e incluso absurdo.

${ }_{86}$ En ocasiones se ha mantenido que, incluso ante penas ya firmes y ejecutadas, la ley posterior que destipifique la conducta debe aplicarse con la consecuencia de la cancelación de los antecedentes penales y la desaparición de la reincidencia como agravante. Así incluso lo entendió la Sala de lo Penal del TS, como recuerda Rodriguez Mourullo (1997, pp. 134-135). Vid. también Muñoz Conde y García Arán, (2019, p. 133). Incluso cabría que el legislador previera compensar a quien sufrió la pena que ahora se considera improcedente. Pero esto último, desde luego, no entra en la retroactividad in melius sino que a lo sumo podrá ser una decisión del legislador, como explica Lascuraín Sanchez (2000, p. 54). Lo mismo vale para el Derecho Administrativo sancionador. Pero sin esa previsión legal no cabe la responsabilidad patrimonial de la Administración y obligarla a indemnizar por haber impuesto y ejecutado una sanción que era legal: el sancionado tenía el deber de soportar el daño que la sanción le irrogó, aunque después se derogase la norma que lo justificó.

87 Así, lo establece el art. 73 de la Ley de la Jurisdicción Contencioso-Administrativa. Y, para el caso de leyes anuladas por inconstitucionalidad, art. 40.1 de la Ley Orgánica del Tribunal Constitucional.

88 En el caso de la declaración de nulidad de normas está en el significado clásico de la nulidad (quod nullum est, nullum producit efectum) que comporta que hay que actuar como si la norma nunca hubiera existido; por eso tiende a la aniquilación de todos los efectos producidos (efectos ex tunc de la nulidad), tendencia que se radicaliza para las normas punitivas. Vid. Rebollo Puig (2018, pp. 512-513). Nada de esto se da en la mera sucesión de normas válidas: al contrario, aquí no se niega la validez y existencia de la norma anterior mientras estuvo vigente; y se basa únicamente en el fundamento de justicia material del que hemos hablado y, desde el punto de vista positivo, en su consagración en tratados internacionales, en la Constitución y en el art. 26.2 LRJSP. 
REALA. Nueva Época - N.o 16, octubre 2021 - ISSN: 1989-8975 - DOI: https://doi.org/10.24965/reala.i16.10961 - [Págs. 6-32]

Sucesión de normas administrativas sancionadoras: irretroactividad y excepciones

Manuel Rebollo Puig

Cabe en primer lugar que la norma sancionadora favorable, aunque posterior a la acción enjuiciada, entre en vigor antes de que se dicte la resolución del procedimiento sancionador ${ }^{89}$. En tal caso, esta resolución debe aplicar ya la norma sancionadora favorable y si no lo hace será anulable por su contrariedad con el artículo 9.3 CE y con el artículo 26.2 LRJSP $^{90}$. Frente a ella se abren sin problemas las vías ordinarias que nuestro Derecho consagra contra los actos administrativos ilegales ${ }^{91}$. Pero no las específicas para la protección de derechos fundamentales: ni el recurso contencioso-administrativo especial de protección de derechos fundamentales ${ }^{92}$ ni el recurso de amparo ${ }^{93}$. Tampoco la revisión de oficio de actos nulos de pleno derecho porque no se está ante tal nulidad.

En segundo lugar, cabe que la norma sancionadora favorable entre en vigor cuando ya se ha dictado la resolución sancionadora pero todavía no ha alcanzado firmeza (da igual que la sanción esté o no ejecutada). Podrá decirse entonces que la resolución sancionadora queda aquejada de una invalidez sobrevenida o tal vez solo que deviene ineficaz. La Administración puede y debe revocar la resolución sancionadora. La vía del artículo 109 LPAC es adecuada. Pero, si no lo hace, ¿son los recursos medio idóneos para imponer la retroactividad in bonus? Cabría negarlo porque cuando el acto administrativo se dictó era plenamente conforme al ordenamiento y porque el carácter revisor de los recursos no permite resolverlos en virtud de normas que la Administración no pudo tener en cuenta cuando actuó. Así lo sostuvieron algunas sentencias. Por ejemplo, STS de 23 de diciembre de 2009 (rec. 3075/2006). Además de declarar que «la fase de casación no es la vía adecuada para declarar esa retroactividad destipificadora que se reclama», con carácter más general dice: «Esa retroactividad, mientras no exista firmeza de la resolución sancionadora, donde debe instarse es en vía administrativa para que, a través del procedimiento contradictorio, se examine y resuelva la procedencia o no de ese efecto destipificador ${ }^{94}$. Pero, atendiendo a razones de justicia y de economía

89 Dice la STS 478/2019, de 8 abril, que «la fecha a tener en cuenta para valorar la conformidad a derecho de la imposición de la sanción será la de la propia resolución sancionadora, pues, si al tiempo de dictarse esta, estuviese en vigor una norma más favorable que la vigente en el momento de cometerse la infracción, la Administración hubiera debido aplicarla por imperativo del artículo 9.3 de la Constitución». No es completa esta afirmación pues, como ya sabemos y como desarrollaremos de inmediato, aunque la norma sancionadora favorable entre en vigor después de la resolución sancionadora también la retroactividad in bonus desplegará sus efectos. Pero sí que da una idea correcta de la forma en que ha de proceder la Administración. Si acaso, cabe distinguir según esa norma favorable entre en vigor antes de que comience el procedimiento sancionador o cuando éste ya esté en curso. En el primer caso, si la nueva norma destipifica la conducta no procederá ni siquiera la iniciación del procedimiento; si solo comporta una disminución de la sanción será la nueva regulación la que desde el acto de incoación habrá de ser la tomada en cuenta. En el segundo caso, es decir, si la ley más favorable entra en vigor cuando ya está iniciado el procedimiento, deberá ser ésta la tenida en cuenta para todos los trámites posteriores. Ocasionalmente será pertinente repetir alguno de los ya practicados para dar al imputado la posibilidad de hacer alegaciones (o hasta proponer prueba) sobre las consecuencias concretas de esa aplicación retroactiva in bonus.

90 Puesto que el TC niega que está irretroactividad favorable esté incluida en el art. 25.1 CE y, consiguientemente, rechaza su protección por medio del recurso de amparo, no se da la causa de nulidad del art. 47.1.a) LPAC ni se atisba ninguna otra causa de nulidad de pleno derecho.

91 Solo hay que añadir que, si eventualmente la Administración no hubiese aplicado la ley sancionadora posterior favorable porque la misma ley lo hubiera excluido, el juez contencioso-administrativo que conozca del asunto, antes de anular la resolución administrativa, deberá elevar cuestión de inconstitucionalidad ante el TC.

92 Así, STS de 30 de enero de 1991 (rec. 3642/1990).

93 SSTC 99/2000, de 10 de abril, 75/2002, de 8 de abril, 85/2006, de 27 de marzo, entre otras. No obstante, en algún caso el TC ha abierto la posibilidad del recurso de amparo frente a la inaplicación de la norma punitiva posterior favorable, pero no con sustento en el art. 25.1 CE sino en algún otro derecho fundamental; destacadamente en el derecho de libertad del art. 17 CE si esa inaplicación de la retroactividad in bonus ha supuesto prisión; o en el del art. 24 a la tutela judicial efectiva por entender que la sentencia que no aplica la norma punitiva favorable posterior supone una resolución judicial arbitraria. Vid. Bueno Armijo (2010, p. 206). Es exponente de ello la STC 99/2000: en un caso en que el tribunal no había aplicado la norma posterior favorable, el TC deniega el amparo basado en el art. $25 \mathrm{CE}$, pero lo otorga por vulneración del art. $24 \mathrm{CE}$ al entender que la sentencia, por esa misma inaplicación, era «manifiestamente irrazonable». En la misma línea y yendo más lejos, se ha dicho que, aunque el art. 25.1 CE no incorpore el derecho a la aplicación retroactiva de la norma posterior favorable, en tanto que sí consagra el derecho a no ser castigado nada más que en virtud de ley, dado el tenor del art. 2.2 CP, cuando no se aplique esa norma penal favorable, sí que se viola el art. 25.1 de la Constitución. En ese sentido, Lascuaraín Sánchez (2000, pp. 29-30). Lo mismo cabría afirmar ante el art. 26.2 LRJSP para el Derecho Administrativo sancionador. En esa dirección Cano Campos (2018, p. 58).

94 Igualmente, STS de 25 de febrero de 2010 (rec. 5920/2004): confirmó la sanción impuesta por la Administración tributaria a Caja de Ahorros Castilla-La Mancha, pero advirtiendo que ello se producía «sin perjuicio de que pueda la Administración tributaria valorar, al ejecutar la sentencia, la posible aplicación retroactiva de la LGT 58/2003, caso de considerarse más favorable para la entidad recurrente». En otros tribunales esta solución encuentra respaldo. Se ve por ejemplo en la STSJ del País Vasco de 29 de junio de 2000. Resolvió el recurso 3927/1998 contra resolución que impuso a un extranjero la sanción de expulsión que preveía la ley vigente cuando la Administración sancionó, pero no la ley vigente cuando se dictó sentencia. Razona que la resolución impugnada era conforme a Derecho (aplicó la sanción prevista por la norma vigente) y que no puede anularla: su validez jurídica no se ve afectada; lo que se ha producido en la «pérdida sobrevenida de ejecutoriedad de las sanciones»; pero esto ya es cuestión que debe resolver la Administración en otra vía. Asimismo, la Sala de Burgos del TSJ de Castilla y León planteó la cuestión en similares términos en una serie de senten- 
REALA. Nueva Época - N.o 16, octubre 2021 - ISSN: 1989-8975 - DOI: https://doi.org/10.24965/reala.i16.10961 - [Págs. 6-32]

Sucesión de normas administrativas sancionadoras: irretroactividad y excepciones

Manuel Rebollo Puig

procesal, los tribunales, en general, tienden a admitir que al resolver recursos contra resoluciones sancionadoras pueden anularlas por su discordancia con la ley más favorable que se aprobó después de ellas, pero antes de dictar sentencia. Es rotunda y representativa la STS de 18 de marzo de 2003 (recurso 5721/1998):

«No podemos compartir el criterio de la sentencia recurrida en el sentido de que el carácter revisor de la Jurisdicción Contencioso-Administrativa impida la aplicación por el Tribunal de una norma sancionadora más favorable aparecida con posterioridad al momento en que se dicta el acto administrativo sancionador (...) Las limitaciones en la fiscalización de los actos administrativos inherentes al principio de jurisdicción revisora (...) no pueden prevalecer frente a una garantía de orden sustantivo del ejercicio de la potestad sancionadora.... $\rangle^{95}$.

Lo que en definitiva se establece es que la aplicación de la norma sancionadora posterior favorable procede en cualquier instancia administrativa o judicial. Incluso se acepta que tribunal proceda de oficio a la aplicación de la norma posterior favorable ${ }^{96}$ y hasta en casación. Es más: por esa vía el TS ha llegado a estimar recursos que en principio eran inadmisibles ${ }^{97}$. Con esa respuesta, sólo queda la duda de si el tribunal debe devolver el asunto a la Administración para que sea ella la que imponga la sanción pertinente conforme a la nueva norma o si la sentencia debe declarar ella misma esa sanción (Gallardo Castillo, 2008, p. 142). Sentencias hay en una y otra línea ${ }^{98}$. Y según el TS las dos opciones son lícitas ${ }^{99}$.

cias sobre los efectos sancionadores favorables de la Ley General Tributaria de 2003. Es buena muestra de esa serie su sentencia 393/2005, de 16 septiembre. También ésta dice que la validez jurídica de la resolución no ha quedado afectada, que es solo cuestión de pérdida sobrevenida de ejecutoridad. Pero sorprendente lo lleva al fallo: «Desestimar el recurso (...) contra la resolución (...) declarando en consecuencia ajustada a derecho la misma, sin perjuicio de que por consecuencia de la entrada en vigor de la Ley 58/2003 General Tributaria, y del régimen sancionador más favorable que establece, reducir (por su pérdida sobrevenida de ejecutividad) el importe de la sanción pecuniaria impuesta a la cuantía de 10.996,21€».

95 En igual sentido, SSTS de 9 de mayo de 2002 (rec. 398/1998); de 24 de enero de 2006 (rec. 419/2002); de 30 de noviembre de 2006 (rec. 6687/2003); de 31 de enero de 2007 (rec. 8873/2003); de 13 de febrero de 2008 (rec. 2110/2004); de 30 de junio de 2010 (rec. 2848/2005). Resultaron esclarecedoras las sentencias que, con ocasión de una reforma de la Ley Orgánica de Protección de Datos, afirmaron que la aplicación de la norma sancionadora posterior favorable procede en cualquier instancia administrativa o judicial [SSTS de 23 y 30 de enero de 2012 (rec. 5962 y 6116/2008), 14 de febrero de 2012 (rec. 462/2008); y 7 de mayo de 2012 (rec. 3346/2009)]. Es curioso, sin embargo, que en su fallo estas sentencias desestiman el recurso y hasta condenan al recurrente en costas. Y luego añaden en el mismo fallo: «No obstante (...) por aplicación retroactiva del régimen sancionador más favorable (...) la infracción ha de ser calificada como grave (no muy grave) y su cuantía reducida al importe de $40.001 € »$. La Sala de lo Militar del TS ha optado decididamente por esa solución como demuestran sus sentencias de 4 de julio de 2005 (rec. 109/2004), de 19 de junio y 17 de julio de 2008 (rec. 21/2007 y 5/2008), de 5 y 23 de marzo de 2009 (rec. 90/2008) y de 28 de septiembre de 2010 (rec. 62/2010). Una síntesis de las sentencias que acogen esta tesis (y de las discordantes) Bueno Armijo (2010, pp. 215-219) y Rebollo Puig (2010, pp. 971-977).

96 Ahora bien, aunque el tribunal pueda introducir de oficio la retroactividad in bonus debe dar audiencia a las partes, incluida la Administración. En este sentido, SSTS de 5 y 7 de mayo de 2010 (recursos 3360 y 3552/2007) que ordenaron reponer las actuaciones al momento anterior a dictar sentencia para que «la Sala de instancia someta la cuestión a las partes, según lo indicado en el art. 33.2 LJCA y resuelva en consecuencia».

97 Así, STS de 14 de febrero de 2013 (rec. 1543/2012). Afirma que «la decisión debía ser de inadmisión del recurso». Pero argumenta que «existe una circunstancia que obliga a conocer de la cuestión planteada y es ésta la que deriva del mandato constitucional (artículo 9.3 de la Constitución, a sensu contrario), que debe ser acatado por los Tribunales, de aplicación de retroactiva de las normas sancionadoras siempre que resulte de ello un tratamiento más beneficioso para al infractor y que se hace extensivo al caso de que una norma posterior elimine la infracción por la que se impuso una sanción, siempre y cuando ésta última no hubiere sido ejecutada». Con estos presupuestos, analiza los hechos recogidos en la sentencia que confirmó la sanción y concluye que los mismos están actualmente destipificados, por lo que anula la sanción.

98 Por ejemplo, como se ha visto, las aludidas SSTS de 23 de enero y 7 de mayo de 2012 (recursos 5962/2008 y 3346/2009) acuerdan ellas mismas imponer la sanción de 40.001€. Igualmente, la STS de 30 de octubre de 2009 (rec. 334/2006), al mismo tiempo que anuló la multa de $90.000 €$, impuso en aplicación de la nueva norma la de $6.000 €$. En dirección contraria, SSTSJ de Madrid 1030 , 1031, 1029, 1057, 1068, 1069/2019 y 31/2020: optan por no aplicar directamente la nueva normativa y retrotraen las actuaciones para que sea la Administración la que dicte una nueva resolución acorde a la norma sancionadora más favorable. Y eso pese a que el mismo Tribunal en sentencia 407/2005, de 17 de marzo, había razonado lo contrario: «... se podría plantear la improcedencia de que un órgano de la jurisdicción realice directamente la aplicación de la ley más favorable, sin dar oportunidad a la Administración para que haga su propia calificación de los hechos»; «la devolución de las actuaciones a la Administración es una de las opciones, pero no la única»; y admite que el tribunal pueda «entrar directamente (...) basándose (...) en una razón de economía procesal». Tras eso impuso por sí misma sanción de $1.000 €$.

99 En esa línea, la STS de 18 de marzo de 2003 (rec. 5721/1998) explica que se trata de una opción en manos de los tribunales de forma que tanto pueden devolver las actuaciones para que los hechos sean «calificados de nuevo por la Administración» como «entrar directamente en el tema, teniendo en cuenta siempre el previo y oportuno debate entre las partes, basándose (...) en una razón de economía procesal». Lo mismo se afirma en la STS de 13 de marzo de 1992 (rec. 3173/1990). La STS 457/2021, de 29 de marzo, explica que «los tribunales, a raíz de un cambio normativo, no siempre pueden fijar por sí mismos la nueva sanción aplicable pues ello exige individualizar la sanción adaptándola al nuevo régimen sancionador y en muchos casos se carece de los datos necesarios para ello». Pero justamente en su caso no ve esos obstáculos y directamente sustituye la multa de $145.700 €$ por la de $36.417 €$. Lo que en 
En tercer lugar, cabe que la norma sancionadora favorable entre en vigor cuando la resolución sancionadora ya ha alcanzado firmeza, pero aún no se ha ejecutado completamente. También en este caso la Administración debe, incluso motu proprio, revocarla por la vía del artículo 109.1 LPAC y declarar que no procede ninguna sanción $\mathrm{o}$, tras audiencia al sancionado, imponer una menor que la inicialmente acordada (Caballero Sánchez, 2001, p. 134); después, o bien no deberá exigir ningún cumplimiento ni proceder a ninguna ejecución forzosa o bien reducirla a la menor sanción resultante. Pero si la Administración no lo hace, el sancionado tiene difícil exigirlo: no tiene la acción del artículo 106.1 LPAC puesto que partimos de que no hay nulidad de pleno derecho; tampoco puede instar la vía del artículo 107 LPAC pues este precepto no la prevé a instancia de los interesados; e igualmente el cauce del artículo 109.1 LPAC no confiere una auténtica acción al interesado (Alenza García, 2017, pp. 189-193). En última instancia, si nada de esto lleva a que la Administración rectifique, el sancionado podría permanecer a la espera de que la Administración dicte algún acto de ejecución forzosa de la sanción impuesta conforme a la ley anterior más severa; y frente a ese acto de ejecución recurrirlo con invocación de la ley favorable posterior. Para el éxito de ese recurso no será obstáculo la firmeza del acto ejecutado ${ }^{100}$.

La situación se complica cuando de las normas que se suceden en el tiempo una prevé pena y otra sanción administrativa. Puede, y no es excepcional, que la ley vigente en el momento de los hechos los tipificase como delito (o falta) y que incluso haya recaído sentencia penal cuando se aprueba otra ley que los convierte en infracción administrativa que, como será normal, comporte un régimen más benigno; a la inversa, puede suceder -aunque es casi hipótesis de laboratorio- que lo que estaba previsto como como infracción administrativa pase a ser delito y que, pese a ello, sea una regulación que, valorada en su conjunto, resulte favorable. Desde luego procede sustituir el castigo (pena o sanción) más grave por el más leve. Pero, como en principio ni el juez puede por sí mismo imponer sanciones administrativas ni menos aún pueden imponer penas las autoridades administrativas, será necesaria la intervención de ambos. Esto dificulta la solución, aunque no la hace imposible ${ }^{101}$. Lo ideal es que la ley que introduzca tal género de reformas prevea algún sistema ad hoc que bien podría consistir en permitir excepcionalmente a los jueces penales acordar la sanción administrativa.

\section{REFERENCIAS BIBLIOGRÁFICAS}

Alarcón Sotomayor, L. (2008). La garantía non bis in idem y el procedimiento administrativo sancionador. lustel.

Alarcón Sotomayor, L. (2012). La prescripción de las infracciones y las sanciones en vía de recurso administrativo (a propósito de la STC 37/2012, de 19 de marzo). Revista Española de Derecho Administrativo, 154, 263-288.

Alenza García, J. F. (2017). Revisión, revocación y rectificación de actos administrativos. Aranzadi.

Boix Palop, A. (2004). Las convalidaciones legislativas. Iustel.

Bueno Armijo, A. (2010). El principio de legalidad sancionadora. En M. Rebollo Puig, M. Izquierdo Carrasco, L. Alarcón Sotomayor y A. Bueno Armijo (coords.), Derecho Administrativo sancionador. Lex Nova.

Caballero Sánchez, F. (2001). Las formas de extinción de la responsabilidad administrativa. Justicia Administrativa, Extra 1 (número extraordinario monográfico dedicado a: Infracciones, sanciones y procedimiento administrativo sancionador), 115-150.

\footnotetext{
ningún caso es necesario ni oportuno es que la Administración tramite íntegramente un nuevo procedimiento sancionador. Sólo si el cambio de regulación fuese tan drástico que los nuevos tipos infractores necesitaran valorar y probar elementos antes no tenidos en cuenta tiene sentido un nuevo procedimiento. De ordinario, bastará una propuesta y un trámite de alegaciones para dictar la resolución que aplique la nueva ley favorable. La sentencia puede ordenarlo así. Y con ello la nueva resolución administrativa podría ser fácilmente controlada en ejecución de sentencia por el tribunal sentenciador y evitar la necesidad de nuevos procesos declarativos.

100 Con frecuencia se afirma que no caben recursos contra los actos de ejecución. Pero las mismas sentencias que lo proclaman rodean esa afirmación de tantas matizaciones que, en realidad, lo que consagran es algo más modesto: la imposibilidad de utilizar los recursos contra los actos de ejecución como medio de alegar los vicios que originariamente tenía el acto ejecutado y que no se invocaron en su momento. Pero cabe la impugnación de los actos de ejecución en tanto que se basen en vicios propios. Vid. Rebollo Puig (2000, pp. 335-340). En el caso que nos ocupa, el acto que pretenda la ejecución forzosa de una resolución sancionadora cuando hay ley posterior que comporta exclusión o reducción de la sanción tiene un vicio propio y específico (que no tenía originariamente la resolución sancionadora) por su contradicción con la regla de la retroactividad in melius cuando la sanción no está completamente ejecutada.

101 Imposible la hace la errónea STC 196/1991: convertida una conducta que era delito en infracción administrativa, la autoridad judicial dejó sin efectos la pena impuesta y, después, la autoridad administrativa, tras procedimiento, impuso la sanción conforme a la nueva ley. Según la STC, esta resolución administrativa viola el art. 25 CE por suponer aplicación retroactiva de la ley administrativa. Para el voto particular, algo más atinado, no es así pero sí que se vulneró la cosa juzgada porque la decisión de la autoridad judicial dejando sin efectos la pena era firme. Pero lo que había era una retroacción de norma punitiva favorable que no vulnera el art. 25 de la Constitución, aunque, en efecto, claro está, supone aplicar una norma sancionadora a hechos cometidos cuando no estaba vigente y porque a esa retroactividad in bonus no es impedimento la cosa juzgada.
} 
REALA. Nueva Época - N.o 16, octubre 2021 - ISSN: 1989-8975 - DOI: https://doi.org/10.24965/reala.i16.10961 - [Págs. 6-32]

Sucesión de normas administrativas sancionadoras: irretroactividad y excepciones

Manuel Rebollo Puig

Cano Campos, T. (2012). La imprescriptibilidad de las sanciones recurridas o la amenaza permanente del «ius puniendi» de la Administración. El Cronista del Estado social y democrático de Derecho, 30, 70-79.

Cano Campos, T. (2014). Las sanciones de tráfico (2. ${ }^{\mathrm{a}}$ ed). Aranzadi.

Cano Campos, T. (2018). Sanciones administrativas. Francis Lefebvre.

Cano Campos, T. (2021). Las sanciones en el estado de alarma. Anuario de Derecho Administrativo sancionador. Civitas.

Cerbo, P. (1999). Le sanzioni amministrative. Giuffrè Editore.

Cimini, S. (2017). II potere sanzionatorio delle amministrazioni pubbliche: uno studio critico. Editoriale scientifica.

Gallardo Castillo, M. J. (2008). Los principios de la potestad sancionadora. Teoría y práctica. lustel.

Gómez Orbaneja, E. y Herce Quemada, V. (1978). Derecho Procesal Penal (10. ${ }^{a}$ ed.).

Gómez Tomillo, M. y Sanz Rubiales, I. (2017). Derecho Administrativo sancionador. Parte General. Aranzadi (4. ${ }^{a}$ ed.).

González Tapia, M. I. (2002). Determinación del tiempo de comisión del delito. Comares.

González Tapia, M. I. (2003). La prescripción en el Derecho Penal español. Dykinson.

Huergo Lora, A. (2021). La publicación del nombre de los infractores como sanción administrativa. En M. Rebollo Puig, A. J. Huergo Lora, J. Guillén Caramés y T. Cano Campos (dirs.), Anuario de Derecho Administrativo sancionador (pp. 93-140). Civitas.

Lascuaraín Sánchez, J. A. (2000). Sobre la retroactividad penal favorable. Civitas.

López Menudo, F. (1982). El principio de irretroactividad en las normas jurídico-administrativas. Instituto García Oviedo.

López Menudo, F. (2010a). Principio de irretroactividad de las disposiciones sancionadoras. En B. Lozano Cutanda (dir.), Diccionario de sanciones administrativas (pp. 721). lustel.

López Menudo, F. (2010b). El principio de irretroactividad. En J. A. Santamaría Pastor (dir.), Los principios jurídicos del Derecho Administrativo (pp. 141-176). La Ley.

López Menudo, F. (2018), Obra escogida. Universidad de Sevilla.

Lozano Cutanda, B. (dir.) (2010). Diccionario de sanciones administrativas. lustel.

Morillas Cueva, L. (2018). Sistema de Derecho Penal. Parte General. Dykinson.

Muñoz Conde, F. y García Arán, M. (2019). Derecho Penal. Parte General (10. a ed.). Tirant lo Blanch.

Muñoz Machado, S. (2015). Tratado de Derecho Administrativo y Derecho público general (tomo III). Boletín Oficial del Estado. https://www.boe.es/biblioteca_juridica/publicacion.php?id=PUB-PB-2015-73\&tipo=L\&modo=2.

Nieto García, A. (2012). Derecho Administrativo sancionador (5. ${ }^{a}$ ed.). Tecnos.

Pagliari, G. (2012). II principio di legalità. En A. Cagnazzo y S. Toschei (coords.), La sanzione amministrativa: principi generali. Giappichelli.

Rebollo Puig, M. (1989). Potestad sancionadora, alimentación y salud pública. INAP.

Rebollo Puig, M. (1992). Comentario a la disposición final segunda. En R. Bercovitz y J. Leguina (coords.), Comentarios a la Ley General para la Defensa de los Consumidores y Usuarios. Civitas.

Rebollo Puig, M. (2000). El procedimiento administrativo de la ejecución subsidiaria. Revista del Poder Judicial, 57 , 321-396.

Rebollo Puig, M. (dir.) e Izquierdo Carrasco, M. (coord.) (2007). Comentarios a la Ley Reguladora de las Bases de Régimen Local. Tirant lo Blanch.

Rebollo Puig, M. (2010). El control contencioso-administrativo de la potestad sancionadora. En M. Rebollo Puig, M. Izquierdo Carrasco, L. Alarcón Sotomayor y A. Bueno Armijo (coords.), Derecho Administrativo sancionador. Lex Nova.

Rebollo Puig, M. (2018). Efectos de las sentencias anulatorias de reglamentos. En especial, su retroactividad. Revista Andaluza de Administración Pública, 100, 469-526. https://doi.org/10.46735/raap.n100.714.

Rodríguez Mourullo, G. (1997). Derecho Penal. Parte General. Civitas.

Rodríguez Santiago, J. M. (2019). Sobre la retroactividad de las normas a los cuarenta años de la Constitución Española. Revista Española de Derecho Administrativo, 202, 51-82.

Ruiz Antón, L. F. (1991). El principio de irretroactividad de la ley penal en la doctrina y la jurisprudencia. Anuario de la Facultad de Derecho. Universidad de Extremadura, 7, 147-167.

Santamaría Pastor, J. A. (1988). Fundamentos de Derecho Administrativo (tomo I). Centro de Estudios Ramón Areces. Villar Palasí, J. L. (1972). Curso de Derecho Administrativo (tomo I). Universidad Complutense de Madrid. 